\title{
Article \\ Growth, Mineral Nutrients, Photosynthesis and Related Physiological Parameters of Citrus in Response to Nitrogen Deficiency
}

\author{
Wei-Tao Huang ${ }^{1}$, Yi-Zhi Xie ${ }^{2}$, Xu-Feng Chen ${ }^{1}$, Jiang Zhang ${ }^{1}$, Huan-Huan Chen ${ }^{1}$, Xin Ye ${ }^{1}$, Jiuxin Guo ${ }^{1}$, \\ Lin-Tong Yang ${ }^{1}$ (D) and Li-Song Chen ${ }^{1, * \mathbb{D}}$ \\ 1 College of Resources and Environment, Fujian Agriculture and Forestry University, Fuzhou 350002, China; \\ 1190807012@fafu.edu.cn (W.-T.H.); 1190807003@fafu.edu.cn (X.-F.C.); 2190807006@fafu.edu.cn (J.Z.); \\ 2200807011@fafu.edu.cn (H.-H.C.); yexin1000@fafu.edu.cn (X.Y.); jxguo@fafu.edu.cn (J.G.); \\ talstoy@fafu.edu.cn (L.-T.Y.) \\ 2 Yongzhou Institute of Agricultural Sciences, Yongzhou 425100, China; oygcxy@163.com \\ * Correspondence: lisongchen@fafu.edu.cn or lisongchen2002@hotmail.com; Tel.: +86-591-8385-4966
}

check for updates

Citation: Huang, W.-T.; Xie, Y.-Z.; Chen, X.-F.; Zhang, J.; Chen, H.-H.; Ye, X.; Guo, J.; Yang, L.-T.; Chen, L.-S. Growth, Mineral Nutrients, Photosynthesis and Related Physiological Parameters of Citrus in Response to Nitrogen Deficiency. Agronomy 2021, 11, 1859. https:// doi.org/10.3390/agronomy11091859

Academic Editors: Othmane Merah, Purushothaman Chirakkuzhyil Abhilash, Magdi T. Abdelhamid, Hailin Zhang and Bachar Zebib

Received: 21 August 2021

Accepted: 15 September 2021

Published: 16 September 2021

Publisher's Note: MDPI stays neutral with regard to jurisdictional claims in published maps and institutional affiliations.

Copyright: (c) 2021 by the authors. Licensee MDPI, Basel, Switzerland. This article is an open access article distributed under the terms and conditions of the Creative Commons Attribution (CC BY) license (https:// creativecommons.org/licenses/by/ $4.0 /)$.

\begin{abstract}
Limited data are available on the physiological responses of Citrus to nitrogen $(\mathrm{N})$ deficiency. 'Xuegan' (Citrus sinensis (L.) Osbeck) and 'Shantian pummelo' (Citrus grandis (L.) Osbeck) seedlings were fertilized with nutrient solution at a $\mathrm{N}$ concentration of $0,5,10,15$ or $20 \mathrm{mM}$ for 10 weeks. $\mathrm{N}$ deficiency decreased $\mathrm{N}$ uptake and $\mathrm{N}$ concentration in leaves, stems and roots and disturbed nutrient balance and homeostasis in plants, thus inhibiting plant growth, as well as reducing photosynthetic pigment levels and impairing thylakoid structure and photosynthetic electron transport chain (PETC) in leaves, hence lowering $\mathrm{CO}_{2}$ assimilation. The imbalance of nutrients intensified $\mathrm{N}$ deficiency's adverse impacts on biomass, PETC, $\mathrm{CO}_{2}$ assimilation and biosynthesis of photosynthetic pigments. Citrus displayed adaptive responses to $\mathrm{N}$ deficiency, including (a) elevating the distributions of $\mathrm{N}$ and other elements in roots, as well as root dry weight (DW)/shoot DW ratio and root-surface-per-unit volume and (b) improving photosynthetic $\mathrm{N}$ use efficiency (PNUE). In general, $\mathrm{N}$ deficiency had less impact on biomass and photosynthetic pigment levels in C. grandis than in C. sinensis seedlings, demonstrating that the tolerance of $C$. grandis seedlings to $\mathrm{N}$ deficiency was slightly higher than that of $C$. sinensis seedlings, which might be related to the higher PNUE of the former.
\end{abstract}

Keywords: Citrus grandis; Citrus sinensis; $\mathrm{CO}_{2}$ assimilation; nitrogen deficiency; photosynthetic nitrogen use efficiency

\section{Introduction}

After carbon, nitrogen $(\mathrm{N})$ is an essential element required in larger amounts by plants than any other elements. N, as a component of chlorophyll (Chl), nucleic acids, amino acids, proteins, plant hormones, coenzymes and secondary metabolites, accounts for $1-5 \%$ of the total plant dry matter. Therefore, $\mathrm{N}$ plays a key role in various metabolic processes of plants such as $\mathrm{Chl}$ biosynthesis and photosynthesis [1,2]. $\mathrm{N}$ is one of the main elements limiting crop productivity, especially in the agricultural system with aerobic soil, in which nitrate is easily leached under the condition of high rainfall [3]. The common $\mathrm{N}$ deficiency symptoms of crops include arrested vegetative growth, leaf yellowing, narrow leaves and reduced yields $[2,4,5]$. To meet the required high crop yields, $\mathrm{N}$ fertilizers have been widely applied [3,6]. The amounts of $\mathrm{N}$ fertilizers applied in the world from $11.4 \mathrm{Tg}$ fertilizer $\mathrm{N}$ year ${ }^{-1}$ in 1961 to $107.7 \mathrm{Tg}$ fertilizer $\mathrm{N}$ year $^{-1}$ in 2019 [7]. Therefore, it is becoming increasingly imperative to find a widely applicable method to lower the amount of $\mathrm{N}$ fertilizer used without reducing yields [8]. Understanding the physiological responses of crops to $\mathrm{N}$ deficiency is key for the improvement of $\mathrm{N}$ use efficiency and the reduction in $\mathrm{N}$ fertilization. 
Leaf $\mathrm{CO}_{2}$ assimilation $\left(\mathrm{A}_{\mathrm{CO} 2}\right)$ relies heavily on the functions of photosynthetic pigments and proteins (enzymes), which occupy the majority of $\mathrm{N}$ in leaves [9-12]. Therefore, $\mathrm{N}$ deficiency causes a decrease in $\mathrm{A}_{\mathrm{CO} 2}$, which is often accompanied by decreases in the concentrations of photosynthetic pigments such as $\mathrm{Chl}$ and carotenoids (Car) and the activities of photosynthetic enzymes such as ribulose-1,5-bisphosphate carboxylase/oxygenase (Rubisco) $[3,9-14]$. $\mathrm{N}$ is highly related to stomatal conductance $\left(\mathrm{g}_{\mathrm{s}}\right)$ and/or stomatal movement [9]. In a study, Zhao et al. [15] suggested that the reduction in $\mathrm{A}_{\mathrm{CO} 2}$ in $\mathrm{N}$ deficiency sorghum leaves was mainly caused by lower $\mathrm{g}_{s}$, because its reduction was accompanied by decreases in both $\mathrm{g}_{\mathrm{s}}$ and intercellular $\mathrm{CO}_{2}$ concentration $\left(\mathrm{C}_{\mathrm{i}}\right)$. However, growing evidence is showing that $\mathrm{N}$-deficiency-induced reduction in leaf $\mathrm{A}_{\mathrm{CO} 2}$ is primarily caused by non-stomatal factors, because the reduction is accompanied by increased $C_{i}$ and / or the ratio of intercellular to ambient $\mathrm{CO}_{2}$ concentration $\left(\mathrm{C}_{\mathrm{i}} / \mathrm{C}_{\mathrm{a}}\right)$, despite the reduced $\mathrm{g}_{\mathrm{s}}[10-12,14,16-19]$.

Scientific reports on $\mathrm{N}$ deficiency's effects on primary photochemistry and electron transport of photosystem II (PSII) are inconsistent. Using Chl $a$ fluorescence techniques, a lot of researches have shown that the reduction in leaf $\mathrm{A}_{\mathrm{CO} 2}$ was associated with a reduced electron transport rate and raised thermal dissipation of absorbed light energy $[9,14,16,20-24]$. However, Cruz et al. [17] indicated that $\mathrm{N}$ deficiency induced a decrease in $\mathrm{A}_{\mathrm{CO} 2}$ in cassava leaves, which was mainly caused by a decline in biochemical capacity for carboxylation, rather than electron transport, in which the maximum PSII efficiency of dark-adapted leaves $\left(\mathrm{F}_{\mathrm{v}} / \mathrm{F}_{\mathrm{m}}\right)$ was not significantly altered by $\mathrm{N}$ deficiency. Unchanged $\mathrm{F}_{\mathrm{v}} / \mathrm{F}_{\mathrm{m}}$ also have been obtained in the N-deficient leaves of sorghum [18], maize and wheat [25]. Polyphasic Chl $a$ fluorescence (OJIP) transients and related fluorescence (OJIP test) parameters have been widely used to reveal the alterations of PSII photochemistry caused by various nutrients deficiencies, such as phosphorus $(\mathrm{P})$, potassium $(\mathrm{K})$, calcium $(\mathrm{Ca})$, sulfur $(\mathrm{S})$, iron $(\mathrm{Fe})$, boron $(\mathrm{B})$, magnesium $(\mathrm{Mg})$, manganese $(\mathrm{Mn})$, copper $(\mathrm{Cu})$ and zinc $(\mathrm{Zn})$ in leaves [26-34]. However, limited information is available on $\mathrm{N}$-deficiency-induced alterations of OJIP transients and OJIP test parameters in leaves. So far, all of these studies have focused on herbs (i.e., maize, tomato, radish and wheat) and shrubs (i.e., tea) $[14,20,25,28,29]$.

There were several studies investigating $\mathrm{N}$ deficiency's effects on the uptake of nutrients and their concentrations in leaves, stems and/or roots, but the results were not unanimous [3,35-41]. For example, the concentrations of $\mathrm{P}, \mathrm{K}, \mathrm{Ca}, \mathrm{Mg}, \mathrm{Mn}, \mathrm{Cu}$ and $\mathrm{Fe}$ in roots and shoots of barley decreased significantly in response to $\mathrm{N}$ deficiency, with a few exceptions that only displayed a decreased trend; but the decreased extent depended on elements, plant tissues and genotypes [38]. $\mathrm{N}$ deficiency increased the concentrations of $\mathrm{P}$ and K in Parthenocissus tricuspidata (Sieb. \& Zucc.) Planch. roots, stems and leaves (mg g ${ }^{-1}$ DW), but decreased their accumulation in roots, stems and leaves (mg plant ${ }^{-1}$ ) [39]. In sugar cane, $\mathrm{N}$ deficiency lowered the concentration of $\mathrm{N}$ in stems and leaves, increased the concentrations of $\mathrm{P}, \mathrm{K}$ and $\mathrm{Mg}$ in leaves and $\mathrm{P}, \mathrm{Mg}$ and $\mathrm{S}$ in roots, decreased the concentration of $\mathrm{Ca}$ in roots, but had little influence on the concentrations of $\mathrm{Ca}$ and $\mathrm{S}$ in leaves and $\mathrm{K}$ in roots. In leaves, $\mathrm{N}$ deficiency led to an increase in the ratio of $\mathrm{P}, \mathrm{K}, \mathrm{Mg}, \mathrm{Ca}$ or $\mathrm{S}$ concentration to $\mathrm{N}$ concentration, while in stems, $\mathrm{N}$ deficiency caused a decrease in the ratio of $\mathrm{N}-, \mathrm{K}-, \mathrm{Ca}-, \mathrm{Mg}$ - or S-to-P concentration [41]. The absence of $\mathrm{N}$ lowered the accumulation of $\mathrm{N}, \mathrm{P}, \mathrm{K}, \mathrm{Mg}, \mathrm{S}$ and $\mathrm{Ca}$ in snap bean shoots [35]. In Spathiphyllum leaves, $\mathrm{N}$ deficiency increased the concentrations of $\mathrm{P}$ and $\mathrm{Ca}$, but it decreased the concentrations of N and K [40]. Nasr Esfahani et al. [42] found that nitrate or phosphate (Pi) imbalance (deficiency) caused stronger molecular responses than combined deficiencies of nitrate and $\mathrm{Pi}$ in chickpea roots and leaves. $\mathrm{N}$ deficiency, therefore, may disturb other nutrient balance and homeostasis, and thus intensify its adverse impacts on growth, biosynthesis of photosynthetic pigments, photosynthetic electron transport chain (PETC) and $\mathrm{A}_{\mathrm{CO} 2}$. To date, such data are very rare.

To deal with $\mathrm{N}$ deficiency, plants have evolved various adaptive mechanisms $[6,8,43-46]$. Many studies have shown that $\mathrm{N}$ deficiency can increase the partitioning of photosynthetic 
dry matter to roots, thus increasing the root/shoot ratio. The increase may be related to the preferential allocation of limited N-to-N-deficient roots [3,6,14,36,39,47-53]. Wang et al. [39] observed that, in addition to increasing $\mathrm{N}$ distribution in $P$. tricuspidata roots, $\mathrm{N}$ deficiency led to an increase in the distributions of $\mathrm{P}$ and $\mathrm{K}$ in roots. In general, $\mathrm{N}$-deficiency-induced decreases in $\mathrm{P}, \mathrm{K}, \mathrm{Mg}, \mathrm{Cu}, \mathrm{Ca}, \mathrm{Fe}$ and $\mathrm{Mn}$ concentrations were less in barley roots than in shoots [38]. Under $\mathrm{N}$ deficiency, the increased distributions of the other nutrient elements in roots might contribute to the higher root/shoot ratio. Increasing evidence shows that the alteration of root architecture in response to $\mathrm{N}$ deficiency plays a key role in enhancing $\mathrm{N}$ acquisition of plants $[6,8,44,45,54]$.

$\mathrm{N}$ is a major factor limiting yield for many crops including Citrus $[5,8,44]$. The optimum range of $\mathrm{N}$ concentration in Citrus leaves is $23-28 \mathrm{~g} \mathrm{~kg}^{-1} \mathrm{DW}$ [55]. Yellow leaves may show when foliar $\mathrm{N}$ concentration ranges from 12.5 to $17.5 \mathrm{~g} \mathrm{~kg}^{-1} \mathrm{DW}$ [5]. Chen et al. [56] indicated that Citrus plants were ammonium sensitive. In China, $\mathrm{N}$ deficiency often occurs in Citrus orchards, which is one of the main causes of yield loss and fruit quality decline [57-61]. Limited data are available on the physiological responses of Citrus to N deficiency $[10,44,45]$. Using Citrus sinensis (L.) Osbeck and Citrus grandis (L.) Osbeck seedlings as materials, we investigated $\mathrm{N}$ deficiency impacts on growth, root architecture (i.e., root length, root surface area, root average diameter and root volume), nutrient elements in leaves, stems and roots, and photosynthetic pigments, gas exchange, OJIP transients and related parameters in leaves. The objectives of this study were (a) to test the hypothesis whether nutritional imbalance aggravates the symptoms of $\mathrm{N}$ deficiency, (b) to understand the possible physiological mechanisms of Citrus adaptation to $\mathrm{N}$ deficiency, and (c) the causes of leaf $\mathrm{A}_{\mathrm{CO} 2}$ decline in response to $\mathrm{N}$ deficiency.

\section{Materials and Methods}

\subsection{Seedling Culture and N Treatments}

Seedling culture and $\mathrm{N}$ treatments were carried out according to Yang et al. [32] with some modifications. Six-week-old uniform 'Xuegan' (Citrus sinensis (L.) Osbeck) and 'Shantian pummelo' (Citrus grandis (L.) Osbeck) seedlings were planted to 6 L pots (two plants pot $^{-1}$ ) filled with sand and cultivated in a greenhouse under natural conditions at Fujian Agriculture and Forestry University, Fuzhou $\left(26^{\circ} 5^{\prime} \mathrm{N}, 119^{\circ} 14^{\prime} \mathrm{E}\right)$ with annual average sunshine hours, temperature and relative humidity of $\sim 1600 \mathrm{~h}, 20^{\circ} \mathrm{C}$ and $76 \%$, respectively [62]. Seven weeks after transporting, each pot was fertilized thrice weekly with nutrient solution at a $\mathrm{N}$ concentration of $0,510,15$ or $20 \mathrm{mM}$ (i.e., macronutrients (Table 1) and micronutrients: $20 \mu \mathrm{M}$ Fe-EDTA, $10 \mu \mathrm{M} \mathrm{H}_{3} \mathrm{BO}_{3}, 2 \mu \mathrm{M} \mathrm{ZnSO}_{4}, 2 \mu \mathrm{M} \mathrm{MnCl}_{2}, 0.5 \mu \mathrm{M}$ $\mathrm{CuSO}_{4}$ and $\left.0.065 \mu \mathrm{M}\left(\mathrm{NH}_{4}\right)_{6} \mathrm{Mo}_{7} \mathrm{O}_{24}\right)$ until part of the nutrient solution started to leak out of the hole at the bottom of the pot $\left(\sim 500 \mathrm{~mL} \mathrm{pot}^{-1}\right)$. Ten weeks after $\mathrm{N}$ treatments, the recent, fully expanded (approximately 7-week-old) leaves were used for all measurements. Firstly, both leaf gas exchange and OJIP transients were measured. Then, $6 \mathrm{~mm}$-diameter leaf discs from the same seedlings used for the above measurements were harvested at a sunny noon and immediately frozen in liquid $\mathrm{N}_{2}$, then stored at $-80{ }^{\circ} \mathrm{C}$ until assay of photosynthetic pigments. These plants unused for disc collection were used for the measurements of biomass and elements.

Table 1. Formula of macronutrients.

\begin{tabular}{|c|c|c|c|c|c|c|c|c|c|c|}
\hline \multirow{2}{*}{$\begin{array}{c}\text { N Levels } \\
(\mathrm{mM})\end{array}$} & \multicolumn{8}{|c|}{ Macronutrients (mM) } & \multirow{2}{*}{$\mathrm{pH}$} & \multirow{2}{*}{$\begin{array}{c}\mathrm{EC} \\
\left(\mathrm{mS} \mathrm{cm}^{-1}\right)\end{array}$} \\
\hline & $\mathrm{K}_{2} \mathrm{SO}_{4}$ & $\mathrm{CaCl}_{2}$ & $\mathrm{MgSO}_{4}$ & $\mathrm{KH}_{2} \mathrm{PO}_{4}$ & $\mathrm{KNO}_{3}$ & $\mathrm{Ca}\left(\mathrm{NO}_{3}\right)_{2}$ & $\left(\mathrm{NH}_{4}\right)_{2} \mathrm{SO}_{4}$ & $\mathrm{NH}_{4} \mathrm{Cl}$ & & \\
\hline 0 & 2.5 & 5 & 2 & 1 & 0 & 0 & 0 & 0 & 6.1 & 3.6 \\
\hline 5 & 1.25 & 5 & 2 & 1 & 2.5 & 0 & 1.25 & 0 & 6.1 & 3.9 \\
\hline 10 & 2.5 & 2.5 & 2 & 1 & 0 & 2.5 & 0 & 5 & 6.1 & 4.3 \\
\hline 15 & 1.25 & 2.5 & 2 & 1 & 2.5 & 2.5 & 1.25 & 5 & 6.1 & 4.7 \\
\hline 20 & 2.5 & 0 & 2 & 1 & 0 & 5 & 0 & 10 & 6.1 & 5.1 \\
\hline
\end{tabular}


2.2. Biomass, Total Root Length, Root Surface Area, Root Average Diameter, Root Volume, and Leaf Photosynthetic Pigments

Leaf, stem and root DW was weighted after being dried to a constant weight at $70{ }^{\circ} \mathrm{C}$.

The image of clean root was captured using digital scanner (Epson Expression 10000XL, Epson America, San Jose, CA, USA) at 600-dpi resolution. Total root length, root surface area, root average diameter and root volume were analyzed using WinRHIZO software (Version 2009b, Regent Instruments, Montreal, QC, Canada) [56].

Leaf Chl, Chl $a, \mathrm{Chl} b$ and carotenoids (Car) were assayed after being extracted with $80 \%$ acetone [63].

\subsection{Elements in Leaves, Stems and Roots}

Recent fully expanded mature leaves, the middle parts of stems and fibrous roots were collected for element analysis. N, K, P, Mg, Ca, S, Mn, Zn, B, Cu and Fe were extracted and measured as described by Cai et al. [64] and Long et al. [65].

Element uptake per plant (plant total element content) was the sum of element content (element concentration $\times$ tissue DW) in leaves, stems and roots. Element uptake per root DW was calculated as plant total element content/root DW. Element distribution in leaves, stems or roots (\%) was calculated as element content in leaves, stems or roots/plant total element $\times 100$, respectively $[64,65]$.

\subsection{Gas Exchange, OJIP Transients and Related Fluorescence Parameters in Leaves}

Gas exchange was made with a CIRAS-2 portable photosynthesis system (PP Systems, Herts, UK) between 9:00 and 11:00 a.m. on a sunny day [26]. Water use efficiency (WUE) and photosynthetic $\mathrm{N}$ use efficiency (PNUE) were calculated as $\mathrm{A}_{\mathrm{CO} 2} /$ transpiration rate (Tr) [62] and $\mathrm{A}_{\mathrm{CO} 2} /$ leaf $\mathrm{N}$ concentration [66], respectively. Leaf OJIP transients were measured after plants had been stored in the dark for $3 \mathrm{~h}$ at room temperature using the Handy PEA (Hansatech Instruments Limited, Norfolk, UK). Fluorescence parameters were calculated according to Kalaji et al. [29] and Jiang et al. [67].

\subsection{Statistical Analysis}

The results were the means \pm SE of 3-12 replicates. Except for the mean OJIP transients (only means), a plant in different pots was a repeat. Data were analyzed by two-way ANOVA (five (N levels) $\times$ two (species)) followed by the least significant difference (LSD) at $p<0.05$ level. Calculation of Pearson correlation coefficients (PCCs) were performed with the SPSS statistical software (version 17.0, IBM Corp., Armonk, NY, USA) [26,68].

\section{Results}

\subsection{Effects of N Supply on Seedling Growth}

As shown in Figure 1, $0 \mathrm{mM}$ N treatment significantly reduced root length, root surface area, root average diameter, root volume, root DW, stem DW, leaf DW, shoot DW and whole plant DW by 30\%, 44\%, 20\%, 55\%, 23\%, 46\%, 49\%, 48\% and 41\%, respectively, in C. grandis seedlings and 29\%, 36\%, 25\%,53\%, 41\%, 67\%, 65\%, 66\% and 58\%, respectively, in C. sinensis seedlings, and significantly increased the ratio of root/shoot DW by $48 \%$ and $74 \%$ in C. grandis and C. sinensis seedlings, respectively, relative to $20 \mathrm{mM} \mathrm{N}$ treatment, while other $\mathrm{N}$ treatments had no significant effect on these ten parameters, with only a few exceptions. The root DW/shoot DW ratio was higher in C. sinensis seedlings than in $C$. grandis seedlings or similar between the two depending on $\mathrm{N}$ supply, while the reverse was the case for the other nine parameters. As shown in Figure S1, N deficiency symptoms such as vein chlorosis or yellow vein in older leaves and weak, yellowish and small new leaves were observed in $0 \mathrm{mM}$ N-treated seedlings, but not in 5-20 mM N-treated seedlings [4,5]. Therefore, seedlings treated with $0 \mathrm{mM} \mathrm{N}$ were considered $\mathrm{N}$ deficient, and those treated with 5-20 mM N were considered $\mathrm{N}$ sufficient. 


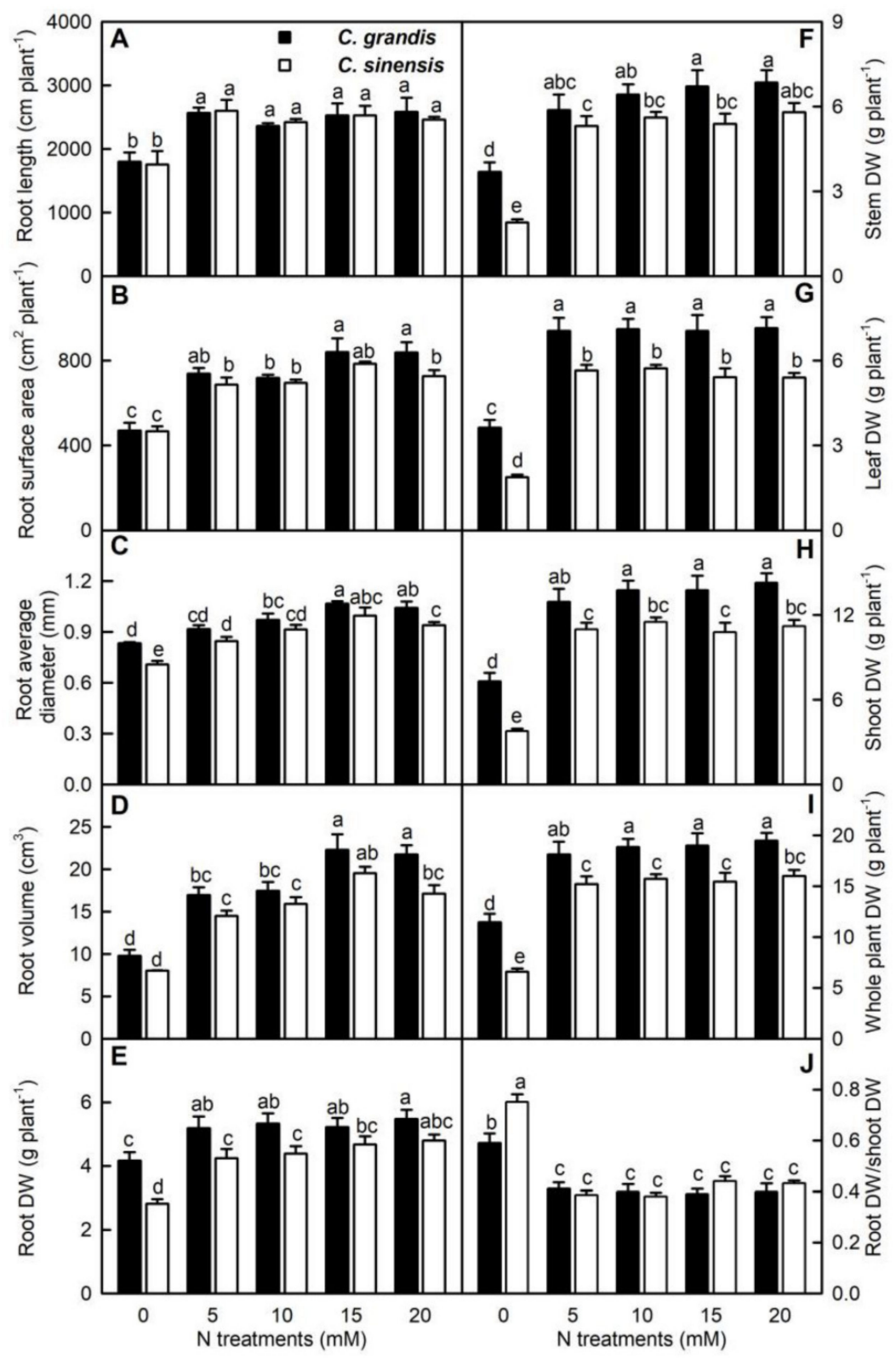

Figure 1. Effects of nitrogen $(\mathrm{N})$ supply on mean $( \pm \mathrm{SE}, n=3-4$ for $(\mathbf{A}-\mathbf{D})$ or 12 for $(\mathrm{E}-\mathrm{J}))$ root length (A), root surface (B), root average diameter $(C)$, root volume (D), root dry weight (DW, (E)), stem DW (F), leaf DW $(\mathbf{G})$, shoot DW (H), whole plant DW (I) and root DW/shoot DW ratio (J) in Citrus grandis and Citrus sinensis seedlings. Different letters above the bars indicate a significant difference at $p<0.05$. The same notation will be used in Figures $2-7$ and 9.

\subsection{Effects of N Supply on Element Concentrations in Roots, Stems and Leaves}

$\mathrm{N}$ concentration in leaves and roots increased with increasing $\mathrm{N}$ supply, and $\mathrm{N}$ concentration in stems increased as $\mathrm{N}$ supply increased from 0 to $5 \mathrm{mM}$, after which it remained relatively stable with the elevating $\mathrm{N}$ supply. $\mathrm{P}$ concentration in $\mathrm{C}$. grandis and $\mathrm{C}$. sinensis leaves, C. sinensis stems and C. grandis roots decreased as $\mathrm{N}$ supply increased from 0 to $5 \mathrm{mM}$, but it then remained unchanged with increasing $\mathrm{N}$ supply; P concentration in C. grandis stems decreased as $\mathrm{N}$ supply increased from 0 to $5 \mathrm{mM}$, but it then rose with increasing $\mathrm{N}$ supply; $\mathrm{P}$ concentration in $\mathrm{C}$. sinensis roots decreased or remained stable as $\mathrm{N}$ supply increased from 0 to $15 \mathrm{mM}$, and then increased at $20 \mathrm{mM} \mathrm{N}$. The concentrations of $\mathrm{K}, \mathrm{Ca}, \mathrm{Mg}$ and $\mathrm{S}$ in leaves, stems and roots decreased or remained stable with increasing $\mathrm{N}$ supply. The concentrations of $\mathrm{N}, \mathrm{K}, \mathrm{Ca}$ and $\mathrm{Mg}$ in leaves, and $\mathrm{P}, \mathrm{K}, \mathrm{Ca}, \mathrm{Mg}$ and $\mathrm{S}$ in roots, 
were higher in C. sinensis seedlings than those in C. grandis seedlings or similar between the two at each given $\mathrm{N}$ supply, while the concentrations of N, P, K, Ca, Mg and S in roots, N in stems, and $\mathrm{P}$ and $\mathrm{S}$ in leaves were higher in $C$. grandis seedlings than those in $C$. sinensis seedlings or similar between the two at each given $\mathrm{N}$ supply, with the exceptions that the concentrations of $P$ and $S$ in $0 \mathrm{mM} \mathrm{N}$-treated leaves and $P$ in 0 and $20 \mathrm{mM} \mathrm{N}$-treated roots were higher in C. sinensis seedlings than those in C. grandis seedlings (Figure 2).
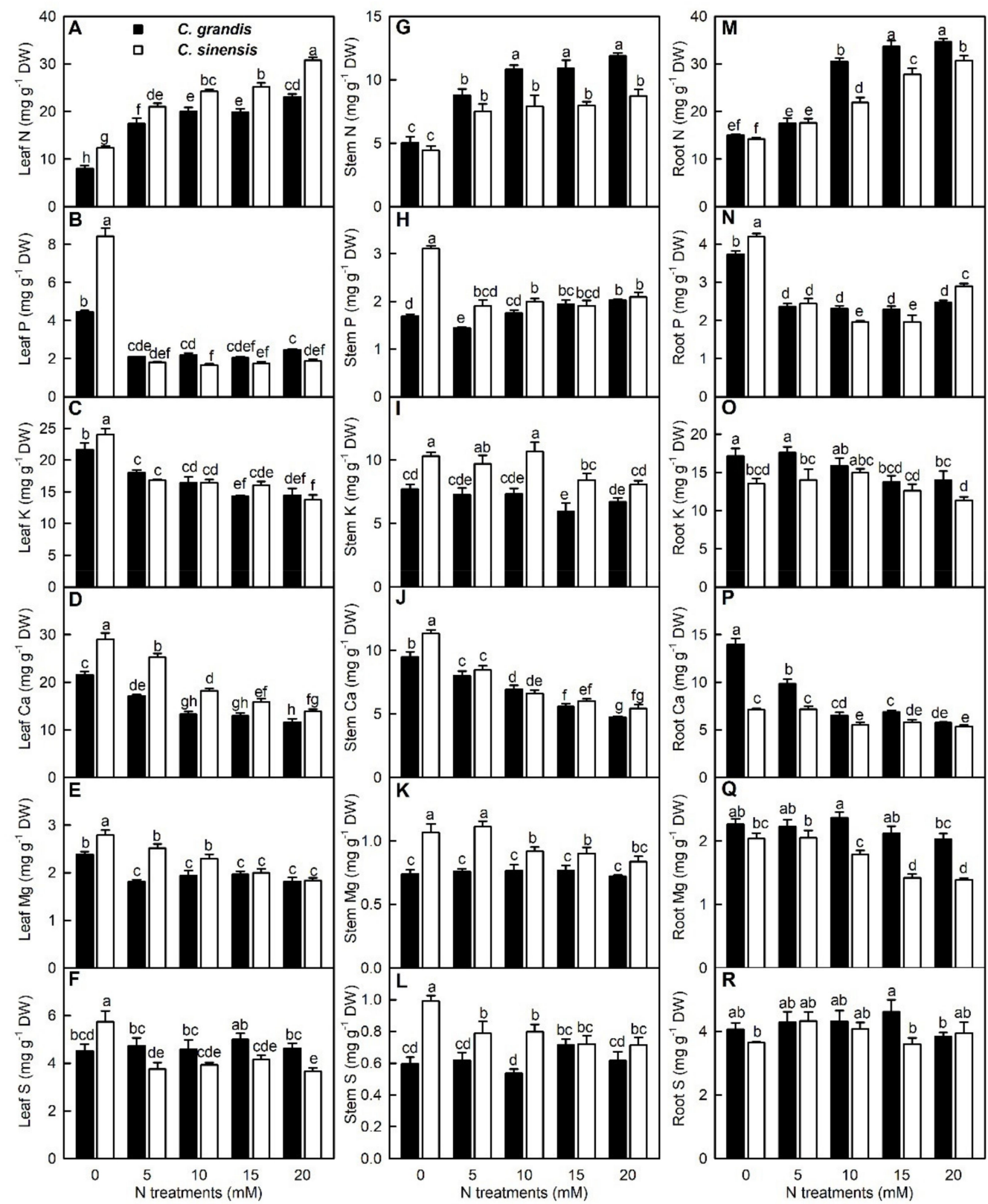

Figure 2. Effects of $\mathrm{N}$ supply on mean $( \pm \mathrm{SE}, n=4)$ concentrations of $\mathrm{N}, \mathrm{P}, \mathrm{K}, \mathrm{Ca}, \mathrm{Mg}$ and $\mathrm{S}$ in leaves (A-F), stems (G-L) and roots (M-R).

Fe concentration in C. grandis and C. sinensis roots and leaves, and C. grandis stems decreased or remained stable with increasing $\mathrm{N}$ supply with the only exception that $\mathrm{Fe}$ concentration in C. grandis leaves was higher at $15 \mathrm{mM} \mathrm{N}$ than at 10 and $20 \mathrm{mM} \mathrm{N}$, while its concentration in $C$. sinensis stems increased or remained unchanged with increasing $\mathrm{N}$ supply. The concentrations of $\mathrm{Mn}$ and $\mathrm{Zn}$ in C. sinensis roots, stems and leaves, $\mathrm{Zn}$ in $\mathrm{C}$. grandis leaves, and $\mathrm{Cu}$ in $\mathrm{C}$. grandis and $\mathrm{C}$. sinensis leaves increased as $\mathrm{N}$ supply increased 
from 0 to $10 \mathrm{mM}$, but they then decreased or remained unchanged with further increasing $\mathrm{N}$ supply. The concentrations of $\mathrm{Mn}$ in C. grandis leaves, stems and roots, $\mathrm{Zn}$ in C. grandis stems and roots, and $\mathrm{Cu}$ in $\mathrm{C}$. grandis roots increased as $\mathrm{N}$ supply increased from 0 to $5 \mathrm{mM}$, and then decreased or remained relatively stable with further increasing $\mathrm{N}$ supply with the only exception that $\mathrm{Mn}$ concentration in stems was higher at $20 \mathrm{mM} \mathrm{N}$ than that at $0-15 \mathrm{mM} \mathrm{N}$. B concentration in leaves was higher at $0 \mathrm{mM} \mathrm{N}$ than that at $5-20 \mathrm{mM} \mathrm{N}$, while its concentration in stems and roots did not significantly alter in response to $\mathrm{N}$ supply. $\mathrm{Cu}$ concentration in stems increased or remained stable with increasing $\mathrm{N}$ supply. The concentrations of $\mathrm{Fe}$ in leaves and stems, $\mathrm{Mn}$ and $\mathrm{Zn}$ in leaves, stems and roots, and $\mathrm{Cu}$ in stems were higher in C. sinensis seedlings than those in C. grandis seedlings or similar between the two at each given $\mathrm{N}$ supply with the only exception that Fe concentration in $0 \mathrm{mM} \mathrm{N}$-treated stems was higher in C. grandis than in $C$. sinensis seedlings, while the concentrations of $\mathrm{Fe}$ in roots, and $\mathrm{Cu}$ in leaves and roots were higher in C. grandis than those in $C$. sinensis seedlings or similar between the two at each given $\mathrm{N}$ supply with the exception that $\mathrm{Cu}$ concentration in $20 \mathrm{mM} \mathrm{N}$-treated leaves and roots was higher in $C$. sinensis seedlings than that in C. grandis seedlings (Figure 3).
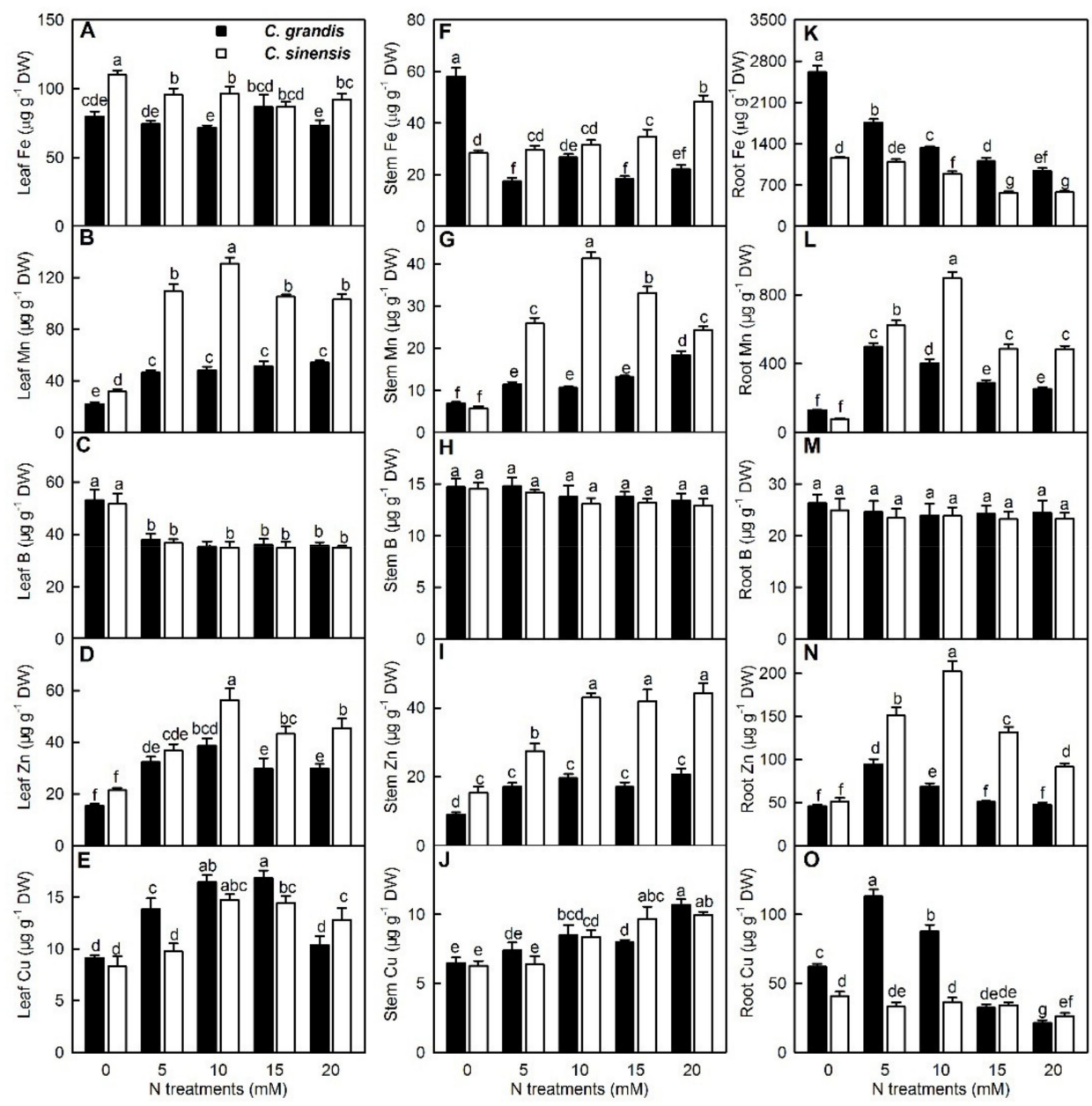

Figure 3. Effects of $\mathrm{N}$ supply on mean $( \pm \mathrm{SE}, n=4)$ concentrations of $\mathrm{Fe}, \mathrm{Mn}, \mathrm{B}, \mathrm{Zn}$ and $\mathrm{Cu}$ in leaves $(\mathbf{A}-\mathbf{E})$, stems $(\mathbf{F}-\mathbf{J})$ and roots $(\mathbf{K}-\mathbf{O})$. 
Compared with $20 \mathrm{mM}$ treatment, $\mathrm{N}$ deficiency significantly increased the ratios of $\mathrm{P} / \mathrm{N}, \mathrm{K} / \mathrm{N}, \mathrm{Ca} / \mathrm{N}, \mathrm{Mg} / \mathrm{N}, \mathrm{S} / \mathrm{N}, \mathrm{Fe} / \mathrm{N}, \mathrm{B} / \mathrm{N}$ and $\mathrm{Cu} / \mathrm{N}$ by $423 \%, 333 \%, 436 \%, 280 \%$, $182 \%, 214 \%, 331 \%$ and $154 \%$, respectively, in C. grandis leaves and by $1022 \%, 336 \%, 420 \%$, $279 \%, 290 \%, 199 \%, 270 \%$ and $62 \%$, respectively, in C. sinensis leaves, by $97 \%, 171 \%, 371 \%$, $142 \%, 128 \%, 520 \%, 158 \%$ and $42 \%$, respectively, in C. grandis stems and by 192\%, 151\%, $310 \%, 151 \%, 1713 \%, 15 \%$ (the only exception without significant difference), $121 \%$ and $24 \%$, respectively, in C. sinensis stems, and by 250\%, 184\%, 463\%, 159\%, 146\%, 427\%, 150\% and $573 \%$, respectively, in C. grandis roots and 212\%, 157\%, 187\%, 216\%, 99\%, 334\%, 131\% and $275 \%$, respectively, in $C$. sinensis roots. The absence of $\mathrm{N}$, therefore, led to an increase in all the eight elements in roots, stems and leaves relative to N. N deficiency lowered Mn/N ratio in C. sinensis leaves, stems and roots by $23 \%, 53 \%$ and $65 \%$, respectively, relative to $20 \mathrm{mM}$ N treatment, but it was similar in C. grandis roots, stems and leaves between 0 and $20 \mathrm{mM}$ treatments. $\mathrm{Zn} / \mathrm{N}$ ratio in C. sinensis leaves and C. grandis roots and leaves was higher at $0 \mathrm{mM} \mathrm{N}$ than that at $20 \mathrm{mM} \mathrm{N}$, but the reverse was the case for $\mathrm{Zn} / \mathrm{N}$ ratio in $C$. sinensis stems. $\mathrm{Zn} / \mathrm{N}$ ratio in $\mathrm{C}$. grandis stems and C. sinensis roots was similar between 0 and $20 \mathrm{mM}$ treatments (Figures S2 and S3).

In leaves, the ratios of $\mathrm{K} / \mathrm{N}, \mathrm{Ca} / \mathrm{N}, \mathrm{Mg} / \mathrm{N}, \mathrm{S} / \mathrm{N}, \mathrm{Fe} / \mathrm{N}, \mathrm{B} / \mathrm{N}$ and $\mathrm{Cu} / \mathrm{N}$ were not significantly lower at $C$. grandis than those at $C$. sinensis at each given $\mathrm{N}$ supply with the exceptions that the ratios of $\mathrm{Ca} / \mathrm{N}$ and $\mathrm{Mg} / \mathrm{N}$ were higher in the latter at $5 \mathrm{mM} \mathrm{N}$; the ratio of $\mathrm{P} / \mathrm{N}$ was higher (lower) in $C$. sinensis than in $C$. grandis at $0 \mathrm{mM}(5-20 \mathrm{mM}) \mathrm{N}$; the ratios of $\mathrm{Mn} / \mathrm{N}$ and $\mathrm{Zn} / \mathrm{N}$ were not significantly lower in $C$. sinensis than in $C$. grandis (Figures S2 and S3).

In stems, the ratios of all the ten elements to $\mathrm{N}$ were higher in $\mathrm{C}$. sinensis than those in C. grandis at given $\mathrm{N}$ supply with a few of exceptions (Figures S2 and S3).

In roots, the ratios of $\mathrm{P} / \mathrm{K}, \mathrm{S} / \mathrm{N}, \mathrm{Mn} / \mathrm{N}, \mathrm{B} / \mathrm{N}$ and $\mathrm{Zn} / \mathrm{B}$ were not significantly lower in $C$. sinensis than those in C. grandis at each given $\mathrm{N}$ supply with the only exception that the ratio of $\mathrm{Mn} / \mathrm{N}$ was significantly lower in the former at $0 \mathrm{mM} \mathrm{N}$, but the ratios of $\mathrm{K} / \mathrm{N}$, $\mathrm{Ca} / \mathrm{N}, \mathrm{Mg} / \mathrm{N}, \mathrm{Fe} / \mathrm{N}$ and $\mathrm{Cu} / \mathrm{N}$ were not significantly lower in $\mathrm{C}$. grandis than those in $\mathrm{C}$. sinensis with the only exception that the ratio of $\mathrm{K} / \mathrm{N}$ was significantly lower in the former at $10 \mathrm{mM} \mathrm{N}$ (Figures S2 and S3).

\subsection{Effects of $N$ Supply on Nutrient Uptake}

For C. grandis seedlings, $\mathrm{N}$ uptake per plant (root DW) increased with increasing $\mathrm{N}$ supply, and Fe uptake per plant (root DW) decreased with increasing $\mathrm{N}$ supply. P uptake per plant (root DW) decreased as $\mathrm{N}$ supply increased from 0 to $5 \mathrm{mM}$, but it then increased or remained relatively stable with further increasing $\mathrm{N}$ supply. $\mathrm{K}, \mathrm{Ca}, \mathrm{Mg}, \mathrm{S}, \mathrm{Cu}, \mathrm{B}, \mathrm{Mn}$ and $\mathrm{Zn}$ uptake per plant (root DW) increased significantly as $\mathrm{N}$ supply increased from 0 to $5 \mathrm{mM}$, after which they decreased or remained relatively stable with further increasing $\mathrm{N}$ supply with the exceptions that Ca and B uptake per root DW did not significantly alter at the range of $0-5 \mathrm{mM} \mathrm{N}$ and that $S$ uptake per root DW was higher at $15 \mathrm{mM}$ than at $10 \mathrm{mM}$. For C. sinensis seedlings, N uptake per plant (root DW) increased with the increase in N supply. P uptake per plant (root DW) decreased or remained stable as $\mathrm{N}$ supply rose from 0 to $15 \mathrm{mM}$, and then reduced at $20 \mathrm{mM} \mathrm{N}$. K, Ca, Mg, S and B uptake per plant (root DW) significantly increased as $\mathrm{N}$ supply rose from 0 to $5 \mathrm{mM}$, but they then decreased or remained relatively stable with the increase in $\mathrm{N}$ supply with the only exception that Fe uptake per root DW did not significantly differ between 0 and $5 \mathrm{mMN}$ treatments. $\mathrm{Cu}, \mathrm{Mn}$ and $\mathrm{Zn}$ uptake per plant (root DW) significantly rose as $\mathrm{N}$ supply rose from 0 to $10 \mathrm{mM}$, and then decreased or did not significantly alter with further increasing N supply (Figure 4). 


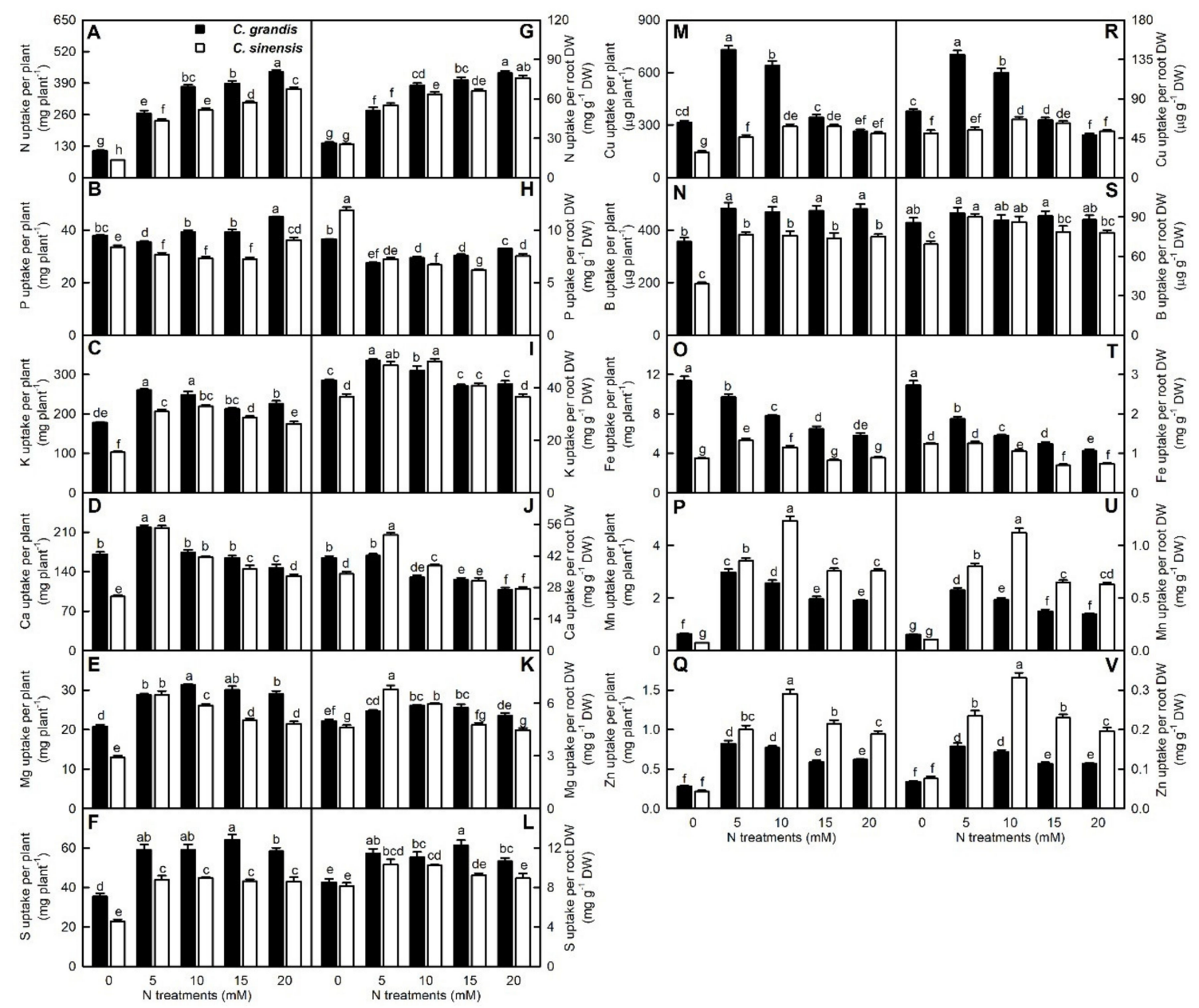

Figure 4. Effects of $\mathrm{N}$ supply on mean $( \pm \mathrm{SE}, n=4)$ element uptake per plant $(\mathbf{A}-\mathbf{F}, \mathbf{M}-\mathbf{Q})$ and per root $\mathrm{DW}(\mathbf{G}-\mathbf{L}, \mathbf{R}-\mathbf{V})$.

As shown in Figure 4, N, P, K, Ca, Mg, Cu, B and Fe uptake per plant (root DW) were higher in $C$. grandis seedlings than those in $C$. sinensis seedlings or similar between the two at each given $\mathrm{N}$ supply with the exceptions that $\mathrm{P}$ uptake per root $\mathrm{DW}$ at $0 \mathrm{mM} \mathrm{N}$, K uptake per root DW at $10 \mathrm{mM} \mathrm{N}$, Ca uptake per root DW at 5 and $10 \mathrm{mM} \mathrm{N}$, and $\mathrm{Mg}$ uptake per root DW at $5 \mathrm{mM} \mathrm{N}$ were higher in C. sinensis than those in C. grandis seedlings, while Mn and Zn uptake per plant (root DW) were higher in C. sinensis than those in C. grandis seedlings or similar between the two at each given $\mathrm{N}$ supply with the exception that $\mathrm{Mn}$ uptake per plant was higher in $C$. grandis than in $C$. sinensis seedlings at $0 \mathrm{mM} \mathrm{N}$.

Generally viewed, the ratios of $\mathrm{P}, \mathrm{K}, \mathrm{Ca}, \mathrm{Mg}, \mathrm{S}, \mathrm{Fe}, \mathrm{B}$ and $\mathrm{Cu}$ uptake per plant to $\mathrm{N}$ uptake per plant increased with the decrease in $\mathrm{N}$ supply, while plant total $\mathrm{Mn} / \mathrm{N}$ and $\mathrm{Zn} / \mathrm{N}$ ratios for $\mathrm{C}$. grandis (C. sinensis) increased significantly as $\mathrm{N}$ supply increased from 0 to 5 (10) $\mathrm{mM}$, then decreased with further increasing $\mathrm{N}$ supply. It is noteworthy that both plant total $\mathrm{Mn} / \mathrm{N}$ and $\mathrm{Zn} / \mathrm{N}$ ratios in C. grandis seedlings were $33 \%$ and $80 \%$ higher at 0 $\mathrm{mM} \mathrm{N}$ than those at $20 \mathrm{mM}$, respectively. The absence of $\mathrm{N}$, thus, caused an increase in the uptake of the 10 elements per plant in $C$. sinensis and C. grandis seedlings relative to $\mathrm{N}$ uptake per plant with the exceptions of $\mathrm{B}$ and $\mathrm{Zn}$ uptake per plant in $\mathrm{C}$. sinensis seedlings. Plant total $\mathrm{P} / \mathrm{N}, \mathrm{Ca} / \mathrm{N}, \mathrm{Mn} / \mathrm{N}$ and $\mathrm{Zn} / \mathrm{N}$ ratios were not significantly lower in $\mathrm{C}$. sinensis than those in $\mathrm{C}$. grandis seedlings with the exceptions that plant total $\mathrm{Ca} / \mathrm{N}$ and $\mathrm{Mn} / \mathrm{N}$ ratios were significantly lower in the former at $0 \mathrm{mM} \mathrm{N}$, while plant total $\mathrm{S} / \mathrm{N}, \mathrm{Fe} / \mathrm{N}$, $\mathrm{B} / \mathrm{N}$ and $\mathrm{Cu} / \mathrm{N}$ ratios were not significantly lower in $\mathrm{C}$. grandis than those in $\mathrm{C}$. sinensis seedlings at each given $\mathrm{N}$ supply. The plants' total $\mathrm{K} / \mathrm{N}$ ratio at $0-5 \mathrm{mM} \mathrm{N}$ and $\mathrm{Mg} / \mathrm{N}$ ratio at 0 and $20 \mathrm{mM} \mathrm{N}$ were significantly higher in $C$. grandis than those in C. sinensis 
seedlings, while plant total $\mathrm{K} / \mathrm{N}$ ratio at $10-15 \mathrm{mM} \mathrm{N}$ and $\mathrm{Mg} / \mathrm{N}$ ratio at 5-10 $\mathrm{mM}$ Nere significantly higher in the latter (Figure 5).

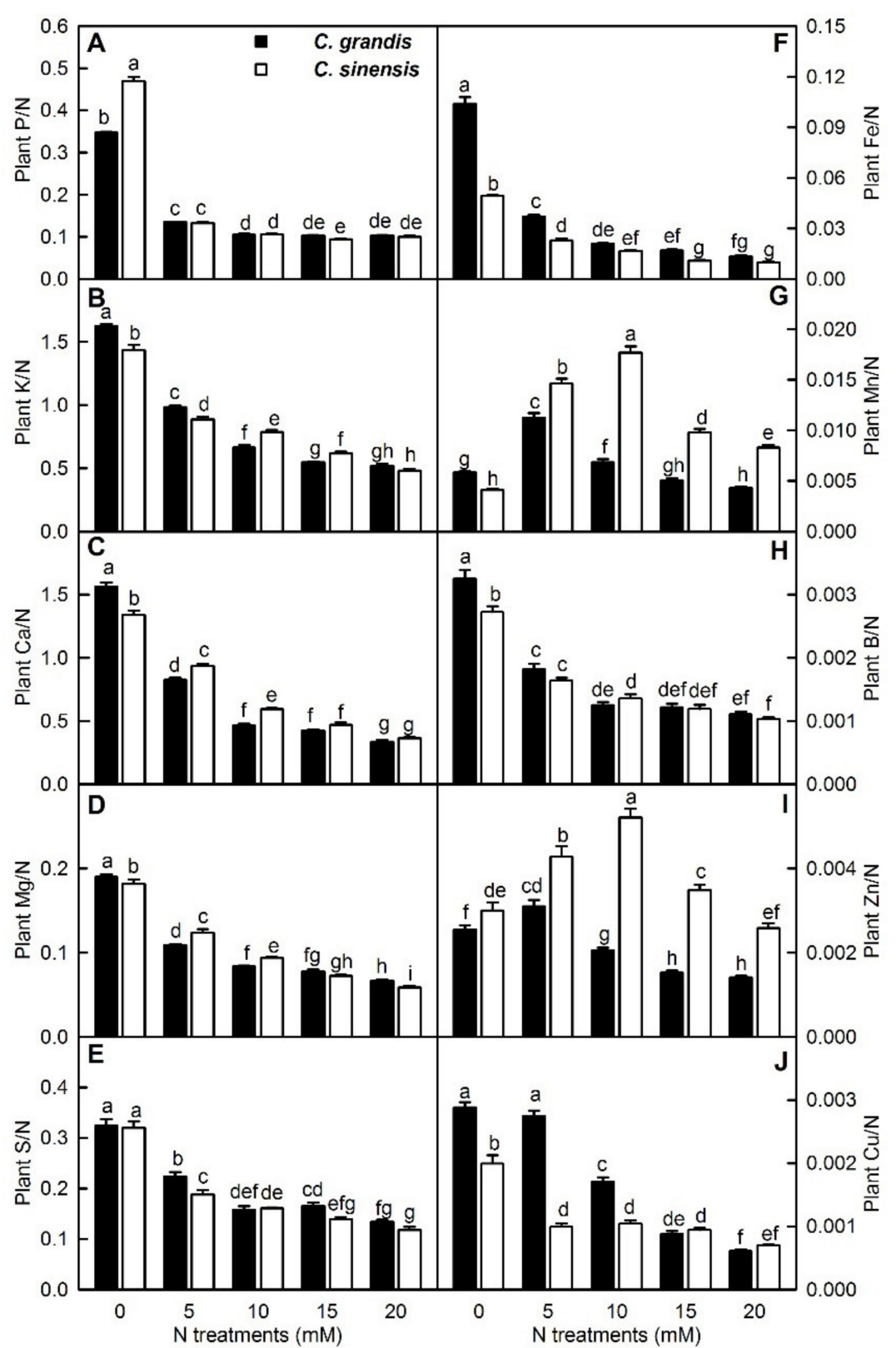

Figure 5. The effects of $\mathrm{N}$ supply on mean $( \pm \mathrm{SE}, n=4)$ ratios of $\mathrm{P}(\mathbf{A}), \mathrm{K}(\mathbf{B}), \mathrm{Ca}(\mathbf{C}), \mathrm{Mg}(\mathbf{D}), \mathrm{S}(\mathrm{E})$, $\mathrm{Fe}(\mathbf{F}), \mathrm{Mn}(\mathbf{G}), \mathrm{B}(\mathbf{H}), \mathrm{Zn}(\mathbf{I})$ and $\mathrm{Cu}(\mathbf{J})$ uptake per plant to $\mathrm{N}$ uptake per plant.

PCCs were calculated for whole plant DW, plant total element content (element uptake per plant) and the ratios of plant total element content to total $N$ content (Figure S4). Wholeplant DW was significantly and positively related to plant total N, B, S, Mg or K content $(r>0.8866)$, and displayed an upward trend with increasing plant total $\mathrm{Cu}, \mathrm{Mn}, \mathrm{Ca}, \mathrm{Zn}$ or $\mathrm{P}$ content; but it was significantly and negatively related to plant total $\mathrm{P} / \mathrm{N}, \mathrm{Mg} / \mathrm{N}, \mathrm{Ca} / \mathrm{N}$, $\mathrm{K} / \mathrm{N}, \mathrm{S} / \mathrm{N}$ or $\mathrm{B} / \mathrm{N}$ ratio $(r<-0.7809)$, and displayed a downward trend with increasing plant total $\mathrm{Fe} / \mathrm{N}, \mathrm{Cu} / \mathrm{N}$ or $\mathrm{Zn} / \mathrm{N}$ ratio. A positive and significant relationship existed between any two parameters of plant total N, B, S, Mg and K contents $(r>0.6366)$ or plant total $\mathrm{P} / \mathrm{N}, \mathrm{Mg} / \mathrm{N}, \mathrm{Ca} / \mathrm{N}, \mathrm{K} / \mathrm{N}, \mathrm{S} / \mathrm{N}$ and $\mathrm{B} / \mathrm{N}$ ratios $(r>0.8728)$. 


\subsection{Effects of N Supply on Element Distributions in Roots, Stems and Leaves}

As shown in Figure S5, N distribution in roots significantly decreased as N supply increased from 0 to $5 \mathrm{mM}$, and then increased or remained relatively stable with increasing $\mathrm{N}$ supply, while $\mathrm{N}$ distribution in stems and leaves significantly rose as $\mathrm{N}$ supply increased from 0 to $5 \mathrm{mM}$, and then decreased or remained unchanged with further increase in $\mathrm{N}$ supply. $\mathrm{P}$ distribution in roots and leaves decreased or remained stable with the increase in $\mathrm{N}$ supply with the only exception that $\mathrm{P}$ distribution in $\mathrm{C}$. sinensis roots was higher at $20 \mathrm{mM} \mathrm{N}$ than at 5-15 $\mathrm{mM} \mathrm{N}$, while P distribution in stems increased with the increase in $\mathrm{N}$ supply with the only exception that $\mathrm{P}$ distribution in $\mathrm{C}$. sinensis stems was lower at $20 \mathrm{mM} \mathrm{N}$ than at $10 \mathrm{mM} \mathrm{N}$. K distribution in roots and leaves did not significantly alter in response to $\mathrm{N}$ supply except for an increase in $\mathrm{K}$ distribution in roots at $0 \mathrm{mM} \mathrm{N}$, while $\mathrm{K}$ distribution in stems increased or remained stable with the increase in $\mathrm{N}$ supply. Ca distribution in roots decreased or remained unchanged as $\mathrm{N}$ supply decreased from 20 to $5 \mathrm{mM} \mathrm{N}$, and then increased at $0 \mathrm{mM} \mathrm{N}$; Ca distribution in leaves significantly increased as $\mathrm{N}$ supply increased from 0 to $5 \mathrm{mM}$, and then decreased or remained stable with further increase in N supply; Ca distribution in stems did not significantly alter in response to $\mathrm{N}$ supply except for an increase in $10 \mathrm{mM} \mathrm{N}$-treated C. grandis and $20 \mathrm{mM} \mathrm{N}$-treated C. sinensis seedlings. Mg distribution in roots decreased or remained unchanged with the increase in $\mathrm{N}$ supply, while the reverse was the case for $\mathrm{Mg}$ distribution in stems and leaves with the only exception that $\mathrm{Mg}$ distribution in leaves was lower in $20 \mathrm{mM} \mathrm{N}$-treated $C$. sinensis than in $10 \mathrm{mM} \mathrm{N}$-treated $C$. sinensis seedlings. $\mathrm{N}$ supply had little influence on $\mathrm{S}$ distribution in roots, stems and leaves except for an increase in $\mathrm{S}$ distribution in $\mathrm{C}$. grandis and $C$. sinensis roots and a decrease in $S$ distribution in $C$. grandis leaves. As shown in Figure $\mathrm{S} 6, \mathrm{Cu}, \mathrm{Fe}, \mathrm{Mn}$ and $\mathrm{Zn}$ distributions in roots decreased or remained unchanged with the increase in $\mathrm{N}$ supply with the exceptions that Mn distribution in C. grandis roots was significantly lower at $0 \mathrm{mM} \mathrm{N}$ than at $5 \mathrm{mM} \mathrm{N}$, and that $\mathrm{Mn}$ distribution in C. sinensis roots was significantly lower at $0 \mathrm{mM} \mathrm{N}$ than at $10 \mathrm{mM} \mathrm{N}$, while their distributions in stems and leaves increased or remained unchanged with the increase in $\mathrm{N}$ supply except that Fe distribution in C. grandis stems was significantly higher at $0 \mathrm{mM} \mathrm{N}$ than at $5 \mathrm{mM} \mathrm{N}$, and that $\mathrm{Cu}$ distribution in $\mathrm{C}$. grandis leaves was significantly higher at $15 \mathrm{mMN}$ than at $20 \mathrm{mM}$ N. N supply had little influence on B distribution in roots, stems and leaves except for an increase in $B$ distribution in $0 \mathrm{mM} \mathrm{N}$-treated $C$. sinensis roots and a decrease in $\mathrm{B}$ distribution in $0 \mathrm{mM} \mathrm{N}$-treated $C$. sinensis stems. Compared with $20 \mathrm{mM}$ treatment, $0 \mathrm{mM}$ $\mathrm{N}$-treated $\mathrm{C}$. grandis seedlings displayed increased distributions of $\mathrm{N}, \mathrm{P}, \mathrm{K}, \mathrm{Ca}, \mathrm{Mg}, \mathrm{S}, \mathrm{Cu}$, $\mathrm{Fe}, \mathrm{B}$ and $\mathrm{Zn}$ in roots and $\mathrm{P}$ in leaves, decreased distributions of $\mathrm{P}, \mathrm{K}, \mathrm{Mg}, \mathrm{Cu}, \mathrm{B}, \mathrm{Mn}$ and $\mathrm{Zn}$ in stems, N, Ca, S, Cu, Fe, Mn and $\mathrm{Zn}$ in leaves, and unaltered distributions of $\mathrm{B}$ in roots, $\mathrm{N}, \mathrm{Ca}, \mathrm{S}$ and $\mathrm{Fe}$ in stems and $\mathrm{K}, \mathrm{Mg}$ and $\mathrm{B}$ in leaves, while $0 \mathrm{mM} \mathrm{N}$-treated $\mathrm{C}$. sinensis seedlings had elevated distributions of $\mathrm{N}, \mathrm{K}, \mathrm{Mg}, \mathrm{Cu}, \mathrm{B}, \mathrm{Fe}$ and $\mathrm{Zn}$ in roots and $\mathrm{P}$ in leaves, reduced distributions of $\mathrm{P}, \mathrm{K}, \mathrm{Mg}, \mathrm{Cu}, \mathrm{B}, \mathrm{Fe}, \mathrm{Mn}$ and $\mathrm{Zn}$ in stems and $\mathrm{N}, \mathrm{Mg}, \mathrm{Cu}, \mathrm{Fe}$ and $\mathrm{Zn}$ in leaves, and unchanged distributions of $\mathrm{P}, \mathrm{Ca}, \mathrm{S}$ and $\mathrm{Mn}$ in roots, $\mathrm{N}, \mathrm{Ca}$ and $\mathrm{S}$ in stems and $\mathrm{K}, \mathrm{Ca}, \mathrm{S}, \mathrm{B}$ and $\mathrm{Mn}$ in leaves. To conclude, $\mathrm{N}$ supply altered element distributions in roots, stems and leaves.

As shown in Figures $\mathrm{S} 5$ and S6, the distributions of N, P, K, Ca, Mg, Cu, Fe and $\mathrm{Mn}$ in roots, $\mathrm{N}$ and $\mathrm{Ca}$ in stems, and $\mathrm{P}, \mathrm{S}$ and $\mathrm{Zn}$ in leaves were higher in $\mathrm{C}$. grandis than those in $C$. sinensis seedlings or similar between the two at each given $\mathrm{N}$ supply except that $C$. sinensis seedlings had higher distributions of $\mathrm{P}$ and $\mathrm{Mn}$ in $20 \mathrm{mM} \mathrm{N}$-treated roots and $\mathrm{P}$ in $0 \mathrm{mM} \mathrm{N}$-treated leaves relative to $C$. grandis seedlings, while the reverse was the case for the distributions of $\mathrm{S}$ and $\mathrm{Zn}$ in roots, $\mathrm{P}, \mathrm{K}, \mathrm{Mg}, \mathrm{S}, \mathrm{Cu}, \mathrm{Fe}, \mathrm{Mn}$ and $\mathrm{Zn}$ in stems and $\mathrm{N}$, $\mathrm{Ca}, \mathrm{Mg}, \mathrm{Cu}, \mathrm{Fe}$ and $\mathrm{Mn}$ in leaves except that $\mathrm{C}$. grandis seedlings had higher distributions of $\mathrm{Cu}$ and $\mathrm{Mn}$ in $20 \mathrm{mM} \mathrm{N}$-treated stems and $\mathrm{Cu}$ in $15 \mathrm{mM} \mathrm{N}$-treated leaves relative to $C$. sinensis seedlings. 


\subsection{Effects of $N$ Supply on Gas Exchange and Photosynthetic Pigments in Leaves}

$\mathrm{N}$ deficiency decreased $\mathrm{A}_{\mathrm{CO} 2}, \mathrm{~g}_{\mathrm{s}}, \mathrm{Tr}$, WUE by $48 \%, 21 \%, 18 \%$ and $36 \%$, respectively, in C. grandis leaves and by $46 \%, 28 \%, 30 \%$ and $24 \%$, respectively, in C. sinensis leaves, but increased $C_{i}$ and $C_{i} / C_{a}$ by $20 \%$ and $21 \%$, respectively, in C. grandis leaves and by $21 \%$ and $20 \%$, respectively, in $C$. sinensis leaves. The six parameters did not significantly alter over the range of 5-20 mM N supply. All the six parameters were similar between $C$. grandis and C. sinensis leaves at each given $\mathrm{N}$ supply with the only exception that $\mathrm{Tr}$ was significantly lower in C. sinensis than in C. grandis leaves at $0 \mathrm{mM} \mathrm{N}$. PNUE, which decreased with the increase in $\mathrm{N}$ supply, was significantly lower in C. sinensis than that in C. grandis leaves at each given $\mathrm{N}$ supply. $\mathrm{N}$ deficiency increased $\mathrm{A}_{\mathrm{CO} 2} / \mathrm{Chl}$ by $22 \%$ in $\mathrm{C}$. sinensis leaves relative to $20 \mathrm{mM} \mathrm{N}$, but not in $C$. grandis leaves. $\mathrm{A}_{\mathrm{CO} 2} / \mathrm{Chl}$ was lower in $C$. grandis leaves than that in C. sinensis leaves at $0 \mathrm{mM} \mathrm{N}$, but it was lower in the latter at 5 and $15 \mathrm{mM} \mathrm{N}$ (Figure 6).

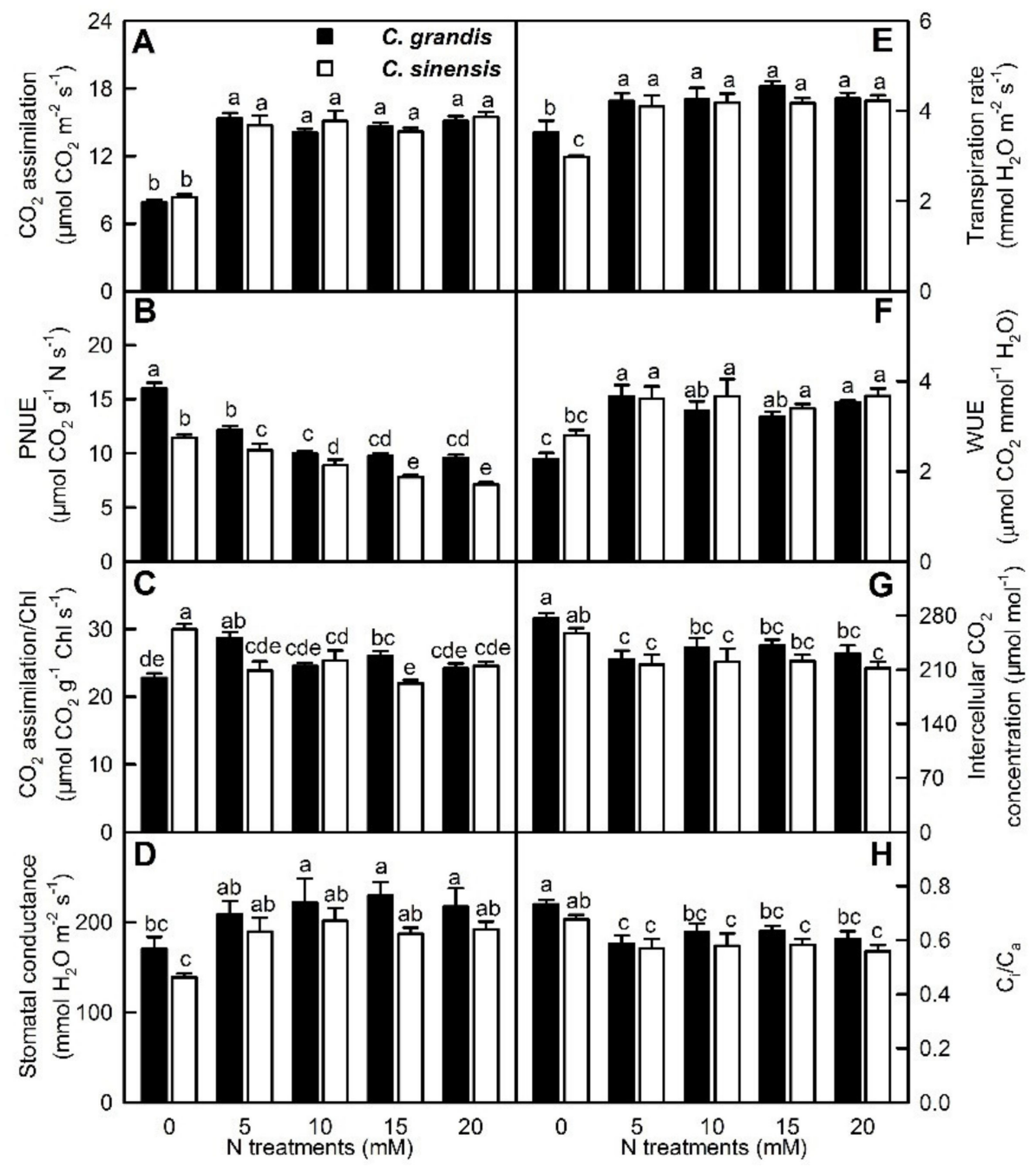

Figure 6. Effects of $\mathrm{N}$ supply on mean $( \pm \mathrm{SE}, n=3-4) \mathrm{CO}_{2}$ assimilation $\left(\mathrm{A}_{\mathrm{CO} 2}\right.$ ( $\left.(\mathrm{A})\right)$, photosynthetic $\mathrm{N}$ use efficiency (PNUE, (B)), $\mathrm{A}_{\mathrm{CO} 2} /$ chlorophyll $(\mathrm{Chl},(\mathbf{C}))$, stomatal conductance $\left(\mathrm{g}_{\mathrm{s}},(\mathbf{D})\right)$, transpiration rate $(\mathrm{Tr},(\mathrm{E}))$, water use efficiency (WUE, $(\mathbf{F}))$, intercellular $\mathrm{CO}_{2}$ concentration $\left(\mathrm{C}_{\mathrm{i}},(\mathrm{G})\right)$ and ratio of intercellular to ambient $\mathrm{CO}_{2}$ concentration $\left(\mathrm{C}_{\mathrm{i}} / \mathrm{C}_{\mathrm{a}},(\mathrm{H})\right)$ in leaves.

$\mathrm{N}$ deficiency significantly reduced $\mathrm{Chl} a, \mathrm{Chl} b, \mathrm{Chl} a+b$ and Car concentrations and Chl $a / b$ ratio by $45 \%, 42 \%, 44 \%, 35 \%$ and $5 \%$, respectively, in C. grandis leaves and by $57 \%$, $55 \%, 56 \%, 48 \%$ and $4 \%$ (the only exception without significant difference), respectively, in C. sinensis leaves, but significantly increased Car/Chl, Chl/ $\mathrm{N}$ and Car $/ \mathrm{N}$ ratios by $14 \%$, $78 \%$ and $102 \%$, respectively, in C. grandis leaves and by $17 \%, 31 \%$ and $54 \%$, respectively, in 
C. sinensis leaves relative to $20 \mathrm{mMN}$. The concentrations of $\mathrm{Chl} a, \mathrm{Chl} b, \mathrm{Chl} a+b$ and Car were higher in $C$. grandis than in $C$. sinensis leaves at $0 \mathrm{mM} \mathrm{N}$, but were not lower in the latter at 5-20 mM N. However, the ratios of $\mathrm{Chl} a / b, \mathrm{Car} / \mathrm{Chl}, \mathrm{Chl} / \mathrm{N}$ and Car/N were not lower in C. grandis leaves than those in C. sinensis leaves at each given $\mathrm{N}$ supply (Figure 7).

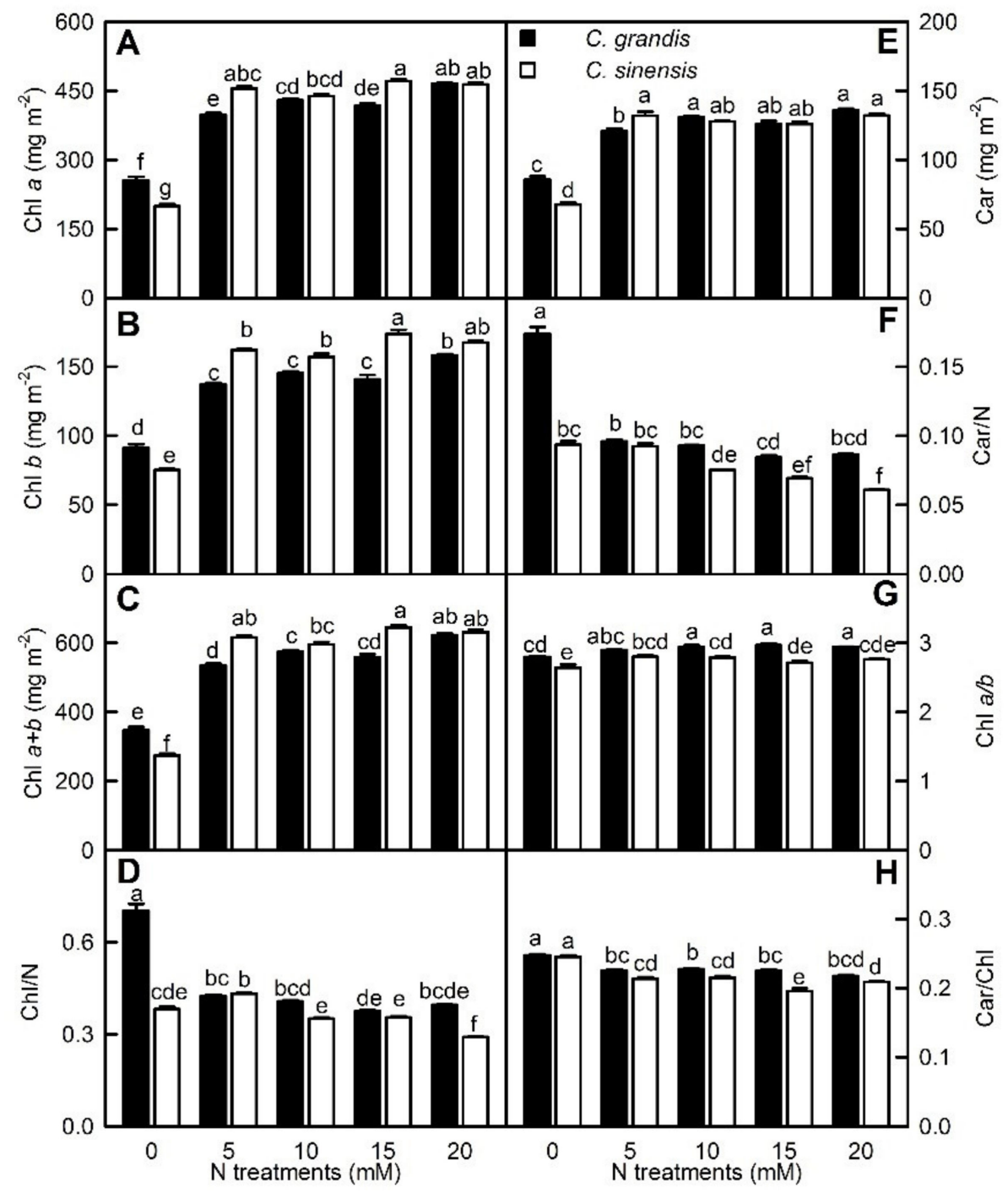

Figure 7. Effects of $\mathrm{N}$ supply on mean $( \pm \mathrm{SE}, n=4) \mathrm{Chl} a(\mathbf{A}), \mathrm{Chl} b(\mathbf{B}), \mathrm{Chl} a+b(\mathbf{C}), \mathrm{Chl} / \mathrm{N}(\mathbf{D})$, carotenoids (Car, E), Car/N (F), Chl $a / b(\mathbf{G})$ and Car/Chl (H) in leaves.

\subsection{Effects of N Supply on OJIP Transients and Related Parameters in Dark-Adapted Leaves}

We observed that the heterogeneity of samples (leaves) was greater at $0 \mathrm{mM}$ than at 5-20 mM N, and that OJIP transients from $\mathrm{N}$ deficiency C. grandis and C. sinensis leaves had greatly increased O-step, slightly increased (C. sinensis) or unaltered (C. grandis) P-step, positive $\Delta \mathrm{L}-, \Delta \mathrm{K}-, \Delta \mathrm{J}$-, and $\Delta \mathrm{I}$-bands, positive $\Delta_{\mathrm{O}-\mathrm{K}}, \Delta_{\mathrm{O}-\mathrm{J}}$ and $\Delta_{\mathrm{J}-\mathrm{I}}$ bands, but negative $\Delta_{\mathrm{I}-\mathrm{P}}$ bands compared with OJIP transients from $20 \mathrm{mM}$-treated leaves, with greater alterations of $\Delta \mathrm{L}$-bands, $\Delta \mathrm{K}$-bands and $\Delta_{\mathrm{I}-\mathrm{P}}$ bands and less alterations of $\Delta_{\mathrm{J}-\mathrm{I}}$ bands in $\mathrm{N}$ deficiency $C$. sinensis than in $\mathrm{N}$ deficiency $C$. grandis leaves. Few, if any, differences existed among the OJIP transients from the 5, 10,15 and $20 \mathrm{~N}$-treated leaves (Figures 8 and S7). 


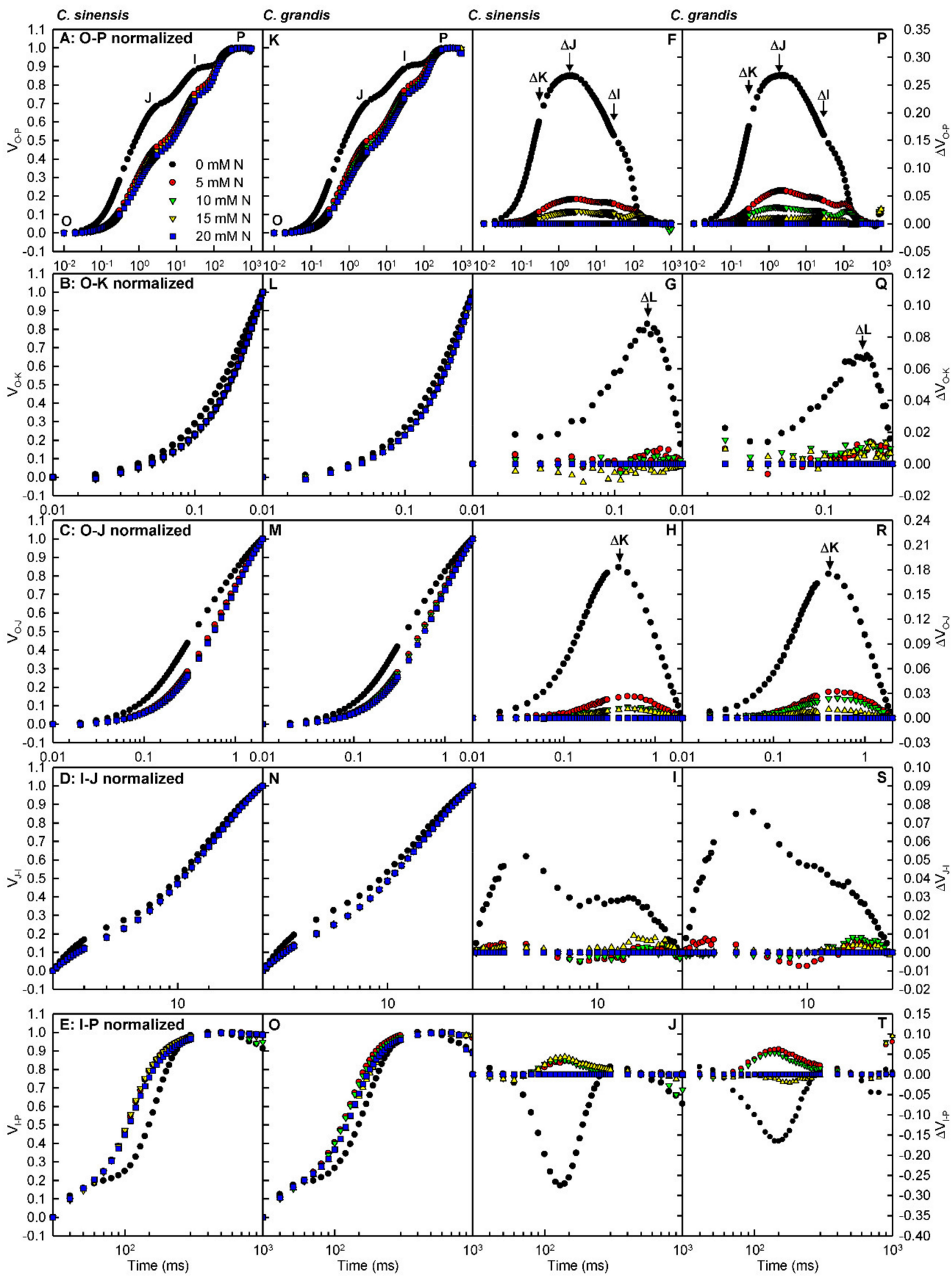

Figure 8. Effects of $\mathrm{N}$ supply on the mean OJIP transients of 10 measured samples expressed as the kinetics of relative variable fluorescence: between $F_{\mathrm{O}}$ and $\mathrm{F}_{\mathrm{m}}\left(\mathrm{O}-\mathrm{P}\right.$ normalized): $\mathrm{V}_{\mathrm{O}-\mathrm{P}}=\left(\mathrm{F}_{\mathrm{t}}-\mathrm{F}_{\mathrm{O}}\right) /\left(\mathrm{F}_{\mathrm{m}}-\mathrm{F}_{\mathrm{O}}\right)(\mathbf{A}, \mathrm{K})$ and the differences of the five samples to the reference sample treated with $20 \mathrm{mM} \mathrm{N}\left(\Delta \mathrm{V}_{\mathrm{O}-\mathrm{P}} ; \mathbf{F}, \mathbf{P}\right)$; between $\mathrm{F}_{\mathrm{O}}$ and $\mathrm{F}_{300 \mu \mathrm{s}}(\mathrm{O}-\mathrm{K}$ normalized): $\mathrm{V}_{\mathrm{O}-\mathrm{K}}=\left(\mathrm{F}_{\mathrm{t}}-\mathrm{F}_{\mathrm{O}}\right) /\left(\mathrm{F}_{300 \mu}-\mathrm{F}_{\mathrm{O}}\right)(\mathbf{B}, \mathrm{L})$ and the differences of the five samples to the reference sample $\left(\Delta \mathrm{V}_{\mathrm{O}-\mathrm{K}} ;(\mathrm{G}, \mathrm{Q})\right)$; between $\mathrm{F}_{\mathrm{O}}$ and $\mathrm{F}_{\mathrm{J}}\left(\mathrm{O}-\mathrm{J}\right.$ normalized): $\mathrm{W}_{\mathrm{O}-\mathrm{J}}=\left(\mathrm{F}_{\mathrm{t}}-\mathrm{F}_{\mathrm{O}}\right) /\left(\mathrm{F}_{\mathrm{J}}-\mathrm{F}_{\mathrm{O}}\right)(\mathbf{C}, \mathbf{M})$ and the differences of the five samples to the reference sample $\left(\Delta \mathrm{V}_{\mathrm{O}-\mathrm{J}} ;(\mathbf{H}, \mathbf{R})\right)$; between $\mathrm{F}_{\mathrm{J}}$ and $\mathrm{F}_{\mathrm{I}}\left(\mathrm{J}\right.$-I normalized): $\mathrm{W}_{\mathrm{J}-\mathrm{I}}=\left(\mathrm{F}_{\mathrm{t}}-\mathrm{F}_{\mathrm{J}}\right) /\left(\mathrm{F}_{\mathrm{I}}-\mathrm{F}_{\mathrm{J}}\right)(\mathbf{D}, \mathbf{N})$ and the differences of the five samples to the reference sample $\left(\Delta \mathrm{V}_{\mathrm{J}-\mathrm{I}} ;(\mathrm{I}, \mathrm{S})\right)$; and between $\mathrm{F}_{\mathrm{I}}$ and $\mathrm{F}_{\mathrm{m}}(\mathrm{I}-\mathrm{P}$ normalized $): \mathrm{V}_{\mathrm{I}-\mathrm{P}}=\left(\mathrm{F}_{\mathrm{t}}-\mathrm{F}_{\mathrm{I}}\right) /\left(\mathrm{F}_{\mathrm{m}}-\mathrm{F}_{\mathrm{I}}\right)(\mathrm{E}, \mathrm{O})$ and the differences of the five samples to the reference sample $\left(\Delta \mathrm{V}_{\mathrm{I}-\mathrm{P}} ;(\mathrm{J}, \mathbf{T})\right)$. 
Our findings showed that $\mathrm{N}$ deficiency decreased maximum primary yield of photochemistry of PSII $\left(\mathrm{F}_{\mathrm{v}} / \mathrm{F}_{\mathrm{o}}\right)$, total electron carriers per reaction center $\left(\mathrm{RC} ; \mathrm{S}_{\mathrm{m}}\right.$ or $\left.\mathrm{EC}_{\mathrm{o}} / \mathrm{RC}\right)$, $\mathrm{F}_{\mathrm{v}} / \mathrm{F}_{\mathrm{m}}\left(\mathrm{TR}_{\mathrm{o}} / \mathrm{ABS}\right)$, quantum yield for electron transport ( $\varphi_{\mathrm{Eo}}$ or $\mathrm{ET}_{\mathrm{o}} / \mathrm{ABS}$ ), efficiency with which an electron can move from the reduced intersystem electron acceptors to the photosystem I (PSI) end electron acceptors $\left(\delta_{\mathrm{Ro}_{\mathrm{o}}}\right.$ or $\left.\mathrm{RE}_{\mathrm{o}} / \mathrm{ET}_{\mathrm{o}}\right)$, quantum yield for the reduction in end acceptors of PSI per photon absorbed ( $\varphi_{R_{0}}$ or $\left.R_{E_{0}} / A B S\right)$, probability that a trapped exciton moves an electron into the electron transport chain beyond $\mathrm{Q}_{\mathrm{A}}{ }^{-}\left(\psi_{\mathrm{Eo}}\right.$ or $\left.\mathrm{ET}_{\mathrm{o}} / \mathrm{TR}_{\mathrm{o}}\right)$, efficiency with which a trapped exciton can move an electron into the electron transport chain from $\mathrm{Q}_{\mathrm{A}}{ }^{-}$to the PSI end electron acceptors $\left(\rho_{\mathrm{Ro}}\right.$ or $\left.\mathrm{RE}_{\mathrm{o}} / \mathrm{TR}_{\mathrm{o}}\right)$, electron transport flux per $\mathrm{RC}\left(\mathrm{ET}_{\mathrm{o}} / \mathrm{RC}\right)$, reduction in end acceptors at PSI electron acceptor side per RC $\left(\mathrm{RE}_{\mathrm{o}} / \mathrm{RC}\right)$, reduction in end acceptors at PSI electron acceptor side per cross section (CS; $\left.\mathrm{RE}_{\mathrm{o}} / \mathrm{CS}_{\mathrm{o}}\right)$, maximum amplitude of IP phase, and total performance index $\left(\mathrm{PI}_{\mathrm{abs}, \text { total }}\right)$ by $26 \%, 49 \%, 6 \%, 48 \%, 23 \%, 60 \%, 45 \%, 58 \%, 14 \%, 34 \%, 48 \%, 65 \%$ and $90 \%$, respectively, in C. grandis leaves and by $26 \%, 45 \%, 5 \%, 47 \%, 22 \%, 58 \%, 44 \%, 56 \%, 9 \%, 29 \%, 44 \%, 64 \%$ and $90 \%$, respectively, in $C$. sinensis leaves, and increased minimum fluorescence $\left(\mathrm{F}_{\mathrm{o}}\right)$, approximated initial slope (in $\mathrm{ms}^{-1}$ ) of the fluorescence transient $V=f(t)\left(M_{0}\right)$, relative variable fluorescence at the J- $\left(2 \mathrm{~ms}, \mathrm{~V}_{\mathrm{J}}\right)$ and $\mathrm{I}-\left(30 \mathrm{~ms}, \mathrm{~V}_{\mathrm{I}}\right)$ steps, absorption flux per RC (ABS/RC), quantum yield for energy dissipation $\left(\mathrm{DI}_{\mathrm{o}} / \mathrm{ABS}\right)$, dissipated energy flux per $\mathrm{RC}\left(\mathrm{DI}_{\mathrm{o}} / \mathrm{RC}\right)$, trapped energy flux per $\mathrm{RC}\left(\mathrm{TR}_{\mathrm{o}} / \mathrm{RC}\right)$, and dissipated energy flux per CS $\left(\mathrm{DI}_{\mathrm{o}} / \mathrm{CS}_{\mathrm{o}}\right.$ ) by $31 \%, 167 \%, 68 \%, 21 \%, 68 \%, 28 \%, 114 \%, 58 \%$ and $67 \%$, respectively, in $\mathrm{C}$. grandis leaves and by $35 \%, 179 \%, 70 \%, 22 \%, 73 \%, 28 \%, 123 \%, 64 \%$ and $74 \%$, respectively, in C. sinensis leaves relative to $20 \mathrm{mM} \mathrm{N}$. Interestingly, $\mathrm{N}$ deficiency increased maximum fluorescence $\left(\mathrm{F}_{\mathrm{m}}\right)$ by $6 \%$ in $C$. sinensis leaves and decreased maximum variable fluorescence $\left(\mathrm{F}_{\mathrm{v}}\right)$ by $4 \%$ in C. grandis leaves relative to $20 \mathrm{mM} \mathrm{N}$, but had no significant impact on both $\mathrm{F}_{\mathrm{m}}$ in $C$. grandis leaves and $\mathrm{F}_{\mathrm{v}}$ in $C$. sinensis leaves. There were relatively little differences in all 24 parameters among 5, 10, 15 and $20 \mathrm{mM} \mathrm{N}$-treated leaves. $\mathrm{F}_{\mathrm{o}}, \mathrm{M}_{\mathrm{O}}, \mathrm{V}_{\mathrm{J}}, \mathrm{V}_{\mathrm{I}}, \mathrm{S}_{\mathrm{m}}, \mathrm{ABS} / \mathrm{RC}$, $\mathrm{ET}_{\mathrm{o}} / \mathrm{ABS}, \mathrm{ET}_{\mathrm{o}} / \mathrm{TR}_{\mathrm{o}}, \mathrm{DI}_{\mathrm{o}} / \mathrm{RC}, \mathrm{TR}_{\mathrm{o}} / \mathrm{RC}, \mathrm{RE}_{\mathrm{o}} / \mathrm{CS}_{\mathrm{o}}$ and maximum amplitude of IP phase did not significantly differ between $C$. grandis and $C$. sinensis leaves except that $F_{O}$ and $\mathrm{V}_{\mathrm{I}}$ at $20 \mathrm{mM} \mathrm{N}$ and $\mathrm{S}_{\mathrm{m}}$ at $15 \mathrm{mM} \mathrm{N}$ were slightly higher in $C$. grandis leaves than in $C$. sinensis leaves, and that $\mathrm{ET}_{\mathrm{o}} / \mathrm{ABS}$ at $5 \mathrm{mM} \mathrm{N}$ was slightly higher in $C$. sinensis than in $C$. grandis leaves. $\mathrm{F}_{\mathrm{m}}, \mathrm{F}_{\mathrm{v}}, \mathrm{F}_{\mathrm{v}} / \mathrm{F}_{\mathrm{o}}, \mathrm{F}_{\mathrm{v}} / \mathrm{F}_{\mathrm{m}}, \mathrm{RE}_{\mathrm{o}} / \mathrm{ET}_{\mathrm{o}}, \mathrm{RE}_{\mathrm{o}} / \mathrm{ABS}, \mathrm{RE}_{\mathrm{o}} / \mathrm{TR}_{\mathrm{o}}, \mathrm{ET}_{\mathrm{o}} / \mathrm{RC}, \mathrm{RE}_{\mathrm{o}} / \mathrm{RC}$ and $\mathrm{PI}_{\mathrm{abs} \text {,total }}$ were higher in $\mathrm{C}$. sinensis than in $\mathrm{C}$. grandis leaves or similar between the two at each given $\mathrm{N}$ supply. $\mathrm{DI}_{\mathrm{O}} / \mathrm{ABS}$ and $\mathrm{DI}_{\mathrm{o}} / \mathrm{CS}_{\mathrm{O}}$ were higher in $C$. grandis than in $C$. sinensis leaves or similar between the two at each given $\mathrm{N}$ supply (Figure 9).

\subsection{Correlation Coefficient Matrices of Gas Exchange, Photosynthetic Pigments, Element Concentrations and Fluorescence Parameters in Leaves}

PCCs were calculated using the means of gas exchange, photosynthetic pigments, element levels and fluorescence parameters in leaves in order to understand the relationships between them (Figure 10). There was a significant negative or positive relationship $(r>0.6349$ or $<-0.6447)$ between any two parameters of the 11 parameters for gas exchange and photosynthetic pigments $\left(\mathrm{C}_{\mathrm{i}} / \mathrm{C}_{\mathrm{a}}, \mathrm{Tr}\right.$, WUE, $\mathrm{A}_{\mathrm{CO} 2}, \mathrm{PNUE}, \mathrm{g}_{\mathrm{s}}, \mathrm{C}_{\mathrm{i}}, \mathrm{Chl} a, \mathrm{Chl} b, \mathrm{Chl}$ and Car) with a few exceptions including the relationships between $C_{\mathrm{i}} / \mathrm{C}_{\mathrm{a}}$ and $\mathrm{g}_{\mathrm{s}}(r=-0.4153)$, WUE and $\mathrm{g}_{\mathrm{S}}(r=0.5439), \mathrm{C}_{\mathrm{i}}$ and $\mathrm{g}_{\mathrm{s}}(r=-0.4096)$, PNUE and $\mathrm{g}_{\mathrm{S}}(r=-0.3309)$, and $\mathrm{Tr}$ and PNUE $(r=-0.5329)$. Leaf $\mathrm{A}_{\mathrm{CO} 2}, \mathrm{Chl}$ or Car was significantly and positively related to leaf $\mathrm{N}, \mathrm{Zn}, \mathrm{Cu}, \mathrm{Mn}, \mathrm{ET}_{\mathrm{o}} / \mathrm{ABS}, \mathrm{ET}_{\mathrm{o}} / \mathrm{TR}_{\mathrm{o}}, \mathrm{RE}_{\mathrm{o}} / \mathrm{CS}_{\mathrm{o}}, \mathrm{F}_{\mathrm{v}} / \mathrm{F}_{\mathrm{m}}, \mathrm{RE}_{\mathrm{o}} / \mathrm{ABS}, \mathrm{RE}_{\mathrm{o}} / \mathrm{TR}_{\mathrm{o}}, \mathrm{F}_{\mathrm{v}} / \mathrm{F}_{\mathrm{o}}$, maximum amplitude of IP phase, $\mathrm{RE}_{\mathrm{o}} / \mathrm{ET}_{\mathrm{o}}, \mathrm{RE}_{\mathrm{o}} / \mathrm{RC}, \mathrm{PI}_{\mathrm{abs}, \text { total }}, \mathrm{S}_{\mathrm{m}}$ or $\mathrm{ET}_{\mathrm{o}} / \mathrm{RC}(r>0.6129)$ with a few exceptions including the relationships between Car and Mn $(r=0.5871)$, Car and $\mathrm{Cu}(r=0.5909)$, and $\mathrm{Chl}$ and $\mathrm{Cu}(r=0.5513)$, and significantly and negatively related to leaf $\mathrm{S}, \mathrm{Ca}, \mathrm{Mg}, \mathrm{P}, \mathrm{K}, \mathrm{B}, \mathrm{Cu} / \mathrm{N}, \mathrm{B} / \mathrm{N}, \mathrm{S} / \mathrm{N}, \mathrm{K} / \mathrm{N}, \mathrm{Ca} / \mathrm{N}, \mathrm{Mg} / \mathrm{N}, \mathrm{Fe} / \mathrm{N}, \mathrm{P} / \mathrm{N}, \mathrm{F}_{\mathrm{O}}, \mathrm{M}_{\mathrm{O}}, \mathrm{V}_{\mathrm{J}}, \mathrm{V}_{\mathrm{I}}$, $\mathrm{ABS} / \mathrm{RC}, \mathrm{DI}_{\mathrm{o}} / \mathrm{ABS}, \mathrm{TR}_{\mathrm{o}} / \mathrm{RC}, \mathrm{DI}_{\mathrm{o}} / \mathrm{RC}$ or $\mathrm{DI}_{\mathrm{o}} / \mathrm{CS}_{\mathrm{o}}(r<-0.6565)$ with a few exceptions including the relationships between $\mathrm{S}$ and $\mathrm{A}_{\mathrm{CO} 2}(r=-0.5549), \mathrm{Cu} / \mathrm{N}$ and $\mathrm{A}_{\mathrm{CO} 2}(r=-0.5882)$, and $\mathrm{Cu} / \mathrm{N}$ and Car $(r=-0.5039)$, while the reverse was the case for PNUE with a few exceptions including PNUE in relation to $\mathrm{Cu}(r=-0.4670), \mathrm{S}(r=0.4122), \mathrm{Ca}(r=0.4477)$, 
$\mathrm{Mg}(r=0.3908)$ and $\mathrm{P}(r=0.4718)$. Leaf $\mathrm{A}_{\mathrm{CO} 2}, \mathrm{Chl}$, Car or PNUE was not significantly related to leaf $\mathrm{F}_{\mathrm{v}}, \mathrm{Mn} / \mathrm{N}, \mathrm{Zn} / \mathrm{N}$, Fe or $\mathrm{F}_{\mathrm{m}}$.
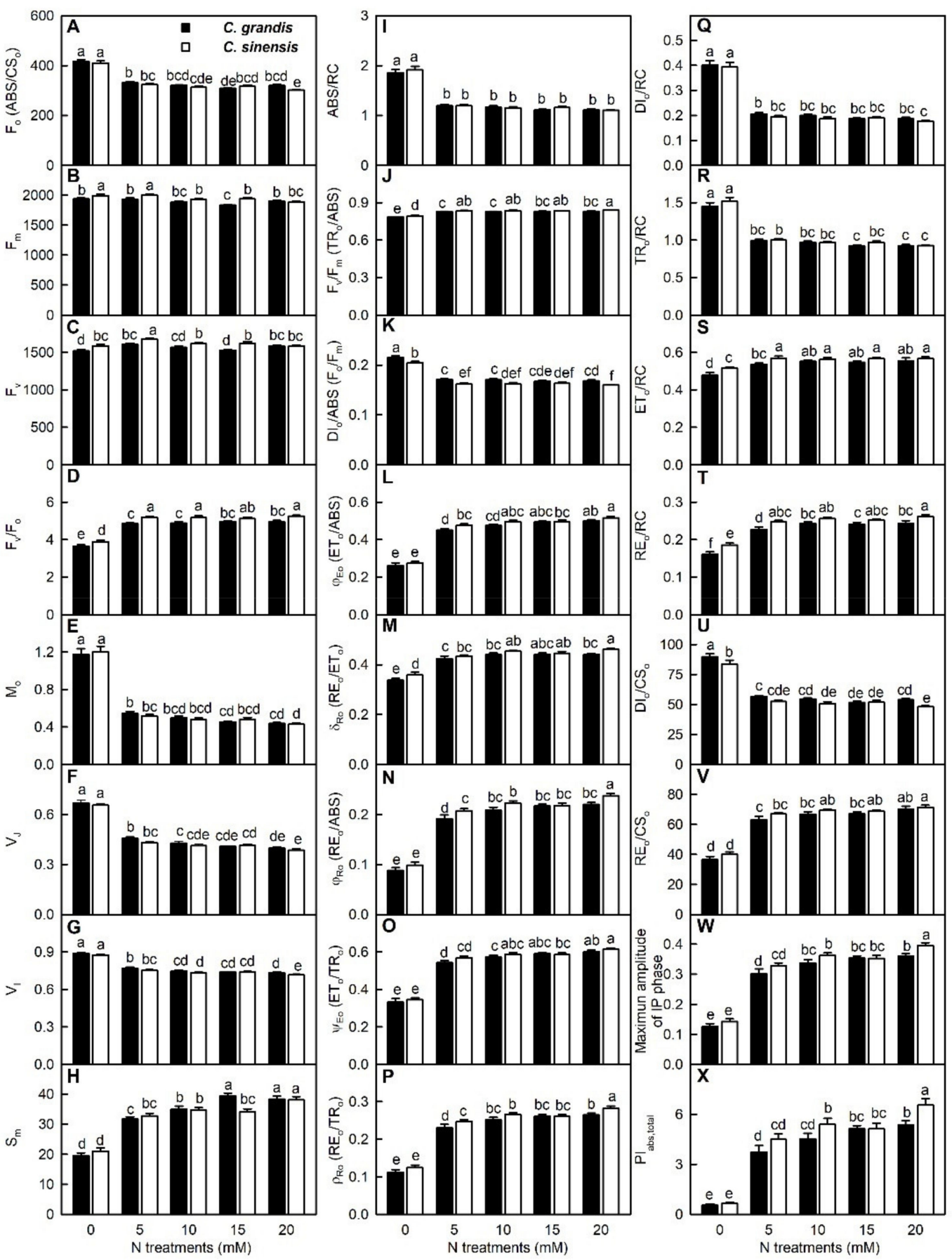

Figure 9. Effects of $\mathrm{N}$ supply on mean $( \pm \mathrm{SE}, n=10) \mathrm{F}_{\mathrm{o}}\left(\mathrm{ABS} / \mathrm{CS}_{\mathrm{o}},(\mathbf{A})\right), \mathrm{F}_{\mathrm{m}}(\mathbf{B}), \mathrm{F}_{\mathrm{v}}(\mathbf{C}), \mathrm{F}_{\mathrm{v}} / \mathrm{F}_{\mathrm{o}}(\mathbf{D}), \mathrm{M}_{\mathrm{o}}(\mathbf{E}), \mathrm{V}_{\mathrm{J}}(\mathbf{F}), \mathrm{V}_{\mathrm{I}}(\mathbf{G}), \mathrm{S}_{\mathrm{m}}$ $\left(\mathrm{EC}_{\mathrm{o}} / \mathrm{RC},(\mathrm{H})\right), \mathrm{ABS} / \mathrm{RC}(\mathrm{I}), \mathrm{F}_{\mathrm{v}} / \mathrm{F}_{\mathrm{m}}\left(\mathrm{TR}_{\mathrm{o}} / \mathrm{ABS},(\mathrm{J})\right), \mathrm{DI}_{\mathrm{o}} / \mathrm{ABS}\left(\mathrm{F}_{\mathrm{o}} / \mathrm{F}_{\mathrm{m}},(\mathrm{K})\right), \varphi_{\mathrm{Eo}}\left(\mathrm{ET}_{\mathrm{o}} / \mathrm{ABS},(\mathbf{L})\right), \delta_{\mathrm{Ro}_{\mathrm{o}}}\left(\mathrm{RE}_{\mathrm{o}} / \mathrm{ET}_{\mathrm{o}},(\mathbf{M})\right), \varphi_{\mathrm{Ro}}$ $\left(\mathrm{RE}_{\mathrm{o}} / \mathrm{ABS},(\mathbf{N})\right), \psi_{\mathrm{Eo}}\left(\mathrm{ET}_{\mathrm{o}} / \mathrm{TR}_{\mathrm{o}},(\mathbf{O})\right), \rho_{\mathrm{Ro}}\left(\mathrm{RE}_{\mathrm{o}} / \mathrm{TR}_{\mathrm{o}},(\mathbf{P})\right), \mathrm{DI}_{\mathrm{o}} / \mathrm{RC}(\mathbf{Q}), \mathrm{TR}_{\mathrm{o}} / \mathrm{RC}(\mathbf{R}), \mathrm{ET}_{\mathrm{o}} / \mathrm{RC}(\mathbf{S}), \mathrm{RE}_{\mathrm{o}} / \mathrm{RC}(\mathbf{T}), \mathrm{DI}_{\mathrm{o}} / \mathrm{CS}_{\mathrm{o}}(\mathbf{U})$, $\mathrm{RE}_{\mathrm{o}} / \mathrm{CS}_{\mathrm{O}}(\mathbf{V})$, maximum amplitude of IP phase $(\mathbf{W})$, and $\mathrm{PI}_{\mathrm{abs}, \text { total }}(\mathbf{X})$ in dark-adapted $C$. grandis and $C$. sinensis leaves. 


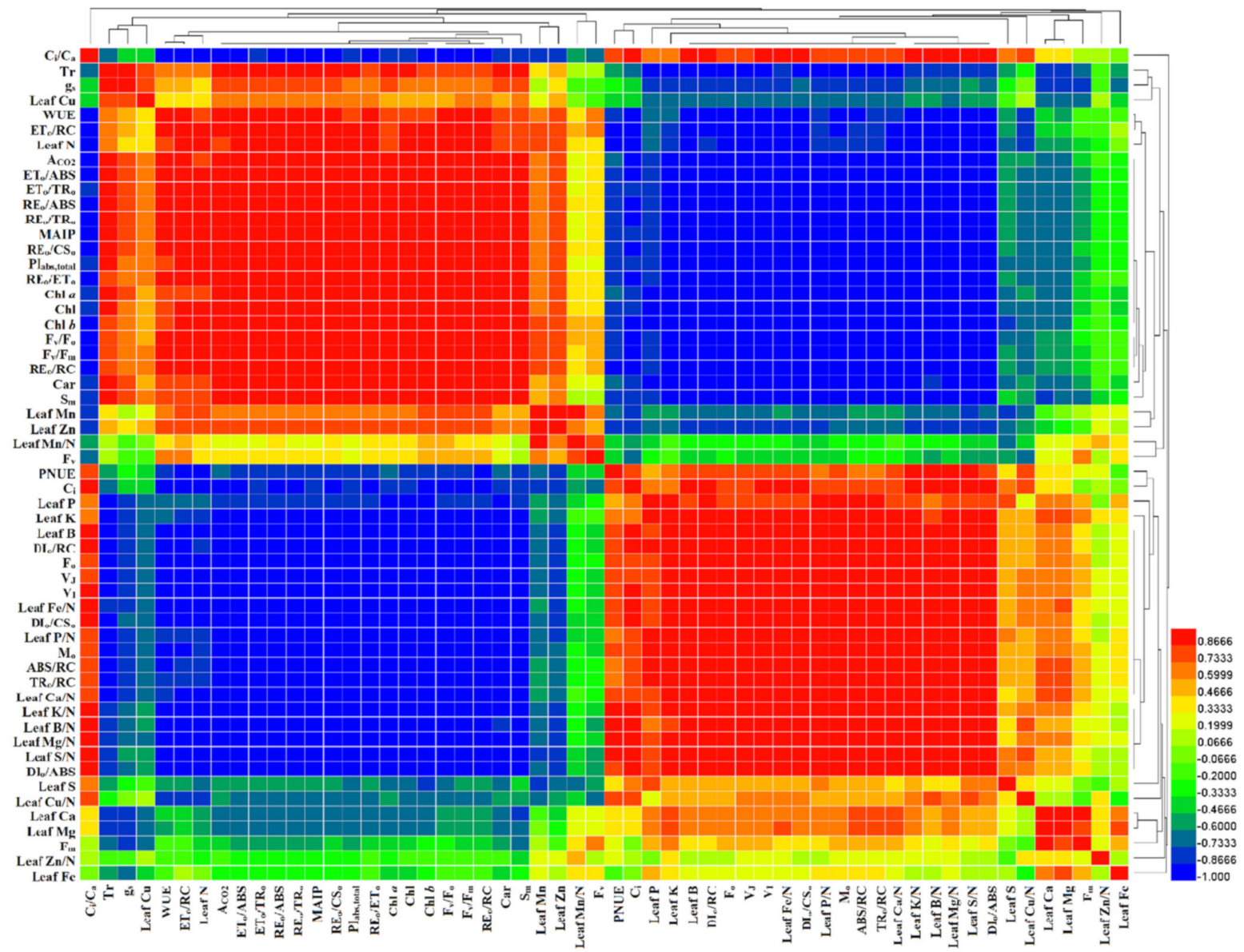

Figure 10. Matrices of Pearson correlation coefficients (PCCs) for the mean gas exchange $(n=3-4)$, photosynthetic pigments $(n=4)$, element concentrations and ratios $(n=4)$ and fluorescence parameters $(n=10)$ in $C$. grandis and $C$. sinensis leaves. $\mathrm{A}_{\mathrm{CO} 2}, \mathrm{CO}_{2}$ assimilation; MAIP, maximum amplitude of IP phase; Tr, transpiration rate. Data for element concentrations and ratios came from Figures 2, 3, S2 and S3. Data for gas exchange and pigments came from Figures 6 and 7 . Data for fluorescence parameters came from Figure 9.

Except for $\mathrm{F}_{\mathrm{m}}$ and $\mathrm{F}_{\mathrm{v}}$, a significant negative or positive relationship existed between any two fluorescence parameters $(r>0.8345$ or $<-0.8392)$.

Leaf $\mathrm{N}$ was significantly and positively related to leaf $\mathrm{A}_{\mathrm{CO} 2}$, Tr, WUE, $\mathrm{Chl} a, \mathrm{Chl} b$, Chl, Car, Mn, Zn, $\mathrm{F}_{\mathrm{v}} / \mathrm{F}_{\mathrm{o}}, \mathrm{S}_{\mathrm{m}}, \mathrm{F}_{\mathrm{v}} / \mathrm{F}_{\mathrm{m}}, \mathrm{ET}_{\mathrm{o}} / \mathrm{ABS}, \mathrm{RE}_{\mathrm{o}} / \mathrm{ET}_{\mathrm{o}}, \mathrm{RE}_{\mathrm{o}} / \mathrm{ABS}, \mathrm{ET}_{\mathrm{o}} / \mathrm{TR}_{\mathrm{o}}, \mathrm{RE}_{\mathrm{o}} / \mathrm{TR}_{\mathrm{o}}$, $\mathrm{ET}_{\mathrm{o}} / \mathrm{RC}, \mathrm{RE}_{\mathrm{o}} / \mathrm{RC}, \mathrm{RE}_{\mathrm{o}} / \mathrm{CS}_{\mathrm{o}}$, maximum amplitude of IP phase or $\mathrm{PI}_{\mathrm{abs}, \text { total }}(r>0.6722)$; and significantly and negatively related to leaf PNUE, $\mathrm{C}_{\mathrm{i}}, \mathrm{C}_{\mathrm{i}} / \mathrm{C}_{\mathrm{a}}, \mathrm{S}, \mathrm{P}, \mathrm{K}, \mathrm{B}, \mathrm{P} / \mathrm{N}, \mathrm{K} / \mathrm{N}, \mathrm{Ca} / \mathrm{N}$, $\mathrm{Mg} / \mathrm{N}, \mathrm{S} / \mathrm{N}, \mathrm{Cu} / \mathrm{N}, \mathrm{Fe} / \mathrm{N}, \mathrm{B} / \mathrm{N}, \mathrm{F}_{\mathrm{o}}, \mathrm{M}_{\mathrm{o}}, \mathrm{V}_{\mathrm{J}}, \mathrm{V}_{\mathrm{I}}, \mathrm{TR}_{\mathrm{o}} / \mathrm{RC}, \mathrm{ABS} / \mathrm{RC}, \mathrm{DI}_{\mathrm{o}} / \mathrm{RC}, \mathrm{DI}_{\mathrm{o}} / \mathrm{CS}_{\mathrm{o}}$ or $\mathrm{DI}_{\mathrm{o}} / \mathrm{ABS}(r<-0.6485)$, but not significantly related to $\mathrm{g}_{\mathrm{s}}, \mathrm{Ca}, \mathrm{Mg}, \mathrm{Fe}, \mathrm{Cu}, \mathrm{Mn} / \mathrm{N}, \mathrm{Zn}, \mathrm{F}_{\mathrm{m}}$ or $\mathrm{F}_{\mathrm{V}}$.

There was a significant and positive relationship between any two parameters of leaf $\mathrm{P}, \mathrm{K}, \mathrm{Ca}, \mathrm{Mg}$ and $\mathrm{B}(r>0.6825)$ or leaf $\mathrm{P} / \mathrm{N}, \mathrm{K} / \mathrm{N}, \mathrm{Ca} / \mathrm{N}, \mathrm{Mg} / \mathrm{N}, \mathrm{S} / \mathrm{N}, \mathrm{Fe} / \mathrm{N}, \mathrm{B} / \mathrm{N}$ and $\mathrm{Cu} / \mathrm{N}(r>0.6372)$ with a few exceptions including $\mathrm{Cu} / \mathrm{N}$ in relation to $\mathrm{P} / \mathrm{N}(r=0.5031)$ and $\mathrm{Ca} / \mathrm{N}(r=0.5870)$.

\section{Discussion}

4.1. The Tolerance of C. grandis Seedlings to N Deficiency Was Slightly Higher than That of C. sinensis Seedlings

Plants need adequate amount of $\mathrm{N}$ for normal growth, development and reproduction. The availability of $\mathrm{N}$ to roots plays a key role in plant growth and photosynthetic pigment biosynthesis $[2,13,35]$. Regressive analysis showed that whole plant DW was positively 
related to $\mathrm{N}$ uptake per plant, but negatively related to the ratio of $\mathrm{P}, \mathrm{Mg}, \mathrm{Ca}, \mathrm{K}, \mathrm{S}$ or $\mathrm{B}$ uptake per plant to $\mathrm{N}$ uptake per plant (Figure S4), and that leaf Chl $a, \mathrm{Chl} b, \mathrm{Chl} a+b$ or Car concentration was positively related to leaf $\mathrm{N}$, but negatively related to leaf $\mathrm{P} / \mathrm{N}$, $\mathrm{K} / \mathrm{N}, \mathrm{Ca} / \mathrm{N} . \mathrm{Mg} / \mathrm{N}, \mathrm{S} / \mathrm{N}, \mathrm{Fe} / \mathrm{N}$ or B/N ratio (Figure 10), suggesting that the imbalance of plant (leaf) nutrients might aggravate the $\mathrm{N}$-deficiency-induced decrease in plant growth (leaf photosynthetic pigment biosynthesis). Here, $\mathrm{N}$ deficiency affected root, stem, leaf, shoot and whole plant DW (Figure 1), and leaf concentrations of Chl $a$, Chl $b, \mathrm{Chl} a+b$ and Car (Figure 7) more in C. sinensis than those in C. grandis seedlings. In addition, $\mathrm{N}$-deficiency-induced alterations of OJIP transients were slightly greater in $\mathrm{C}$. sinensis than those in $C$. grandis leaves, as indicated by the more pronounced positive $\Delta \mathrm{V}_{\mathrm{O}-\mathrm{K}}$ and $\Delta \mathrm{V}_{\mathrm{O}-\mathrm{J}}$ bands, and negative $\Delta \mathrm{V}_{\mathrm{I}-\mathrm{P}}$ band with the exception that the positive $\Delta \mathrm{V}_{\mathrm{J}-\mathrm{I}}$ band was more pronounced in C. grandis leaves than that in C. sinensis leaves (Figure 8). These results indicated that C. grandis seedlings had slightly higher tolerance to $\mathrm{N}$ deficiency than that of $C$. sinensis seedlings. PNUE increases in response to $\mathrm{N}$ deficiency. A higher PNUE can make plants use $\mathrm{N}$ effectively for biomass production and improve $\mathrm{N}$ use efficiency. There were genotypic differences in PNUE of maize and olives, and PNUE in N-efficient genotypes was higher than that of $\mathrm{N}$-inefficient genotype. A genotypic difference in PNUE has in fact been observed in maize, and PNUE of N-efficient genotypes was higher than that of N-inefficient genotype $[69,70]$. Boussadia et al. [66] found that PNUE increased in $\mathrm{N}$ deficiency 'Meski' olive leaves, but remained unchanged in 'Koroneiki' olive leaves, concluding that 'Meski' had an improvement of $\mathrm{N}$ budget in its leaves than 'Koroneiki', and hence might be better adapted to $\mathrm{N}$ deficiency. The higher tolerance of $C$. grandis to $\mathrm{N}$ deficiency could be explained in this way, because $\mathrm{N}$-deficiency-induced increase in PNUE was greater in C. grandis than that in C. sinensis leaves and PNUE was higher in the former than in the latter at each given N supply (Figure 6).

\subsection{N Deficiency Disturbed Nutrient Balance and Homeostasis, and Altered Nutrient Distributions in Roots, Stems and Leaves}

$\mathrm{N}$ has both antagonism and synergism on other elements, affecting the uptake and distributions of other elements, and ultimately determining the contents of other elements in different organs of plants [3,37]. Here, N deficiency increased or did not affect $\mathrm{P}, \mathrm{K}$, $\mathrm{Ca}, \mathrm{Mg}, \mathrm{S}, \mathrm{Fe}$ and $\mathrm{B}$ concentrations in roots, stems and leaves and $\mathrm{Cu}$ concentration in roots with the exceptions that $\mathrm{N}$ deficiency lowered the concentrations of $\mathrm{P}$ in $\mathrm{C}$. grandis stems and $\mathrm{Fe}$ in $\mathrm{C}$. sinensis stems (Figures 2 and 3). $\mathrm{N}$ deficiency led to an increase in the ratios of $\mathrm{P}, \mathrm{K}, \mathrm{Ca}, \mathrm{Mg}, \mathrm{S}, \mathrm{Fe}, \mathrm{B}$ and $\mathrm{Cu}$ concentrations to $\mathrm{N}$ concentration in roots, stems and leaves (Figures $\mathrm{S} 2$ and $\mathrm{S} 3$ ), and the ratios of $\mathrm{P}, \mathrm{K}, \mathrm{Ca}, \mathrm{Mg}, \mathrm{S}, \mathrm{Fe}, \mathrm{B}$ and $\mathrm{Cu}$ uptake per plant to $\mathrm{N}$ uptake per plant (Figure 5) in C. sinensis and C. grandis seedlings relative to $20 \mathrm{mMN}$ treatments with the exception that the ratio of stem Fe/ $\mathrm{N}$ in $\mathrm{C}$. sinensis seedlings did not significantly differ between $0 \mathrm{mM}$ and $20 \mathrm{mM} \mathrm{N}$ treatments. Therefore, $\mathrm{N}$ had antagonistic effect on the uptake of these elements. In maize, Schlüter et al. [71] observed that N-starvation led to a strong accumulation of $\mathrm{Pi}$ in leaves accompanied by the downregulation of genes involved in Pi-starvation response, demonstrating the importance of Pi homeostasis in stress adaption. Excessive $\mathrm{N}$ supply was considered as a cause of Citrus $\mathrm{Cu}$ deficiency in Florida [5]. There was report showing that $\mathrm{N}$ absorption could lower the uptake of $\mathrm{P}$ and $\mathrm{K}$ in plants [37]. Additionally, $\mathrm{N}$ deficiency affected $\mathrm{Mn}$ and $\mathrm{Zn}$ concentrations and the ratios of $\mathrm{Mn} / \mathrm{N}$ and $\mathrm{Zn} / \mathrm{N}$ in roots, stems and leaves, as well as the ratios of $\mathrm{Mn}(\mathrm{Zn})$ uptake per plant to $\mathrm{N}$ uptake per plant in C. grandis and C. sinensis seedlings with the exceptions that $\mathrm{Zn}$ concentration and $\mathrm{Mn} / \mathrm{N}$ in C. grandis roots, $\mathrm{Zn} / \mathrm{N}$ in $C$. sinensis roots and Zn uptake per plant/N uptake per plant in $C$. sinensis seedlings did not differ significantly between 0 and $20 \mathrm{mM} \mathrm{N}$ treatments (Figures 3, 5 and S3). Lack of N, therefore, altered nutrient uptake per plant to $\mathrm{N}$ uptake per plant, thus distributed nutrient balance and homeostasis in leaves, stems and roots. N-deficiency-induced imbalance of nutrients has been obtained in peace lily leaves [40], sugar cane leaves and stems [41], barley [49], grapevine [72], pear [3], Cyclocarya paliurus (Batal.) Iljinskaja [37], snap bean [35] and sorghum [36]. 
The distributions of 11 elements in roots were not significantly lower at $0 \mathrm{mM}$ than those at $20 \mathrm{mM}$, while the reverse was the case for their distributions in leaves and stems with the exceptions that $\mathrm{P}$ distributions in leaves was significantly higher at $0 \mathrm{mM} \mathrm{N}$ than that at $20 \mathrm{mM} \mathrm{N}$ (Figures S4 and S5). On the whole, lack of N, therefore, increased the distributions of nutrients in roots, but decreased their distributions in shoots. N-deficiencyinduced increase in N, P, K distributions in roots has been obtained in P. tricuspidata [39] and maize [6] plants.

\subsection{Citrus Displayed Adaptive Responses to N Deficiency}

In addition to suppressing plant growth, $\mathrm{N}$ deficiency also affects dry matter allocation $[15,50]$. According to the classical theory of 'functional equilibrium' between shoots and roots, under $\mathrm{N}$ deficiency, both the relative deficiency of $\mathrm{N}$ and the relative surplus of carbohydrates in plants will have less influence on root development than on shoot development [52]. Here, root DW decreased to a less extent than shoot DW in response to $\mathrm{N}$ deficiency, and the ratio of root DW/shoot DW increased (Figure 1). Similar reports for increased partitioning of photosynthetic dry matter to the roots and the increase in the ratio of root DW/shoot DW are well recorded for other $\mathrm{N}$ deficiency plants including Betula pendula Roth. [51], maize [6,52], lettuce [73], peace lily [40], wheat [48,74,75], sorghum [15], swithgrass [76], pear [3], P. tricuspidata [39], soybean [53], snap bean [35], rice [47], sweet potato [77], chickpea [42] and pumpkin [50]. Our results demonstrated that among the four parameters (root length, root surface area, root average diameter and root volume) for root architecture, root volume had the greatest decrease under $\mathrm{N}$ deficiency, thus leading to increased root-surface-per-unit volume (Figure 1). Plasticity of root architecture plays a role in the acclimation to $\mathrm{N}$ deficiency [6]. Yang et al. [48] observed that low $\mathrm{N}$-induced increase in the ratio of root DW/shoot DW was greater in a newly formed hexaploid wheat with stronger tolerance to $\mathrm{N}$ deficiency than its parents, which might be an adaptive growth strategy for the hexaploid because relative more roots fed relative less shoots with $\mathrm{N}$, thereby causing higher $\mathrm{N}$ accumulation in the shoots. Active elongation of thin roots to search for $\mathrm{N}$ has also been considered as the survival strategy for plants [50]. Thus, $\mathrm{N}$-deficiency-induced increases in the root-surface-per-unit volume due to reduced root diameter and the ratio of root DW/ shoot DW might facilitate $\mathrm{N}$ uptake and acquisition, thus improving Citrus tolerance to $\mathrm{N}$ deficiency. However, the difference in $\mathrm{N}$ deficiency tolerance between $C$. sinensis and $C$. grandis could not be explained in this way, because $\mathrm{N}$-deficiency-induced increase in the ratio was greater in the former than in the latter (Figure 1). Under low-N stress, $\mathrm{N}$ rather than carbon should be the most limited resource for root growth [46]. Here, we observed that $\mathrm{N}$ concentration reduced to a less extent in $\mathrm{N}$ deficiency roots than that in $\mathrm{N}$ deficiency stems and leaves, and $\mathrm{N}$ deficiency increased $\mathrm{N}$ distribution in roots (Figures 2 and S2), indicating that the limited $\mathrm{N}$ in $\mathrm{N}$ deficiency seedlings was preferentially allocated to the roots to maintain their growth. To conclude, $\mathrm{N}$ deficiency Citrus seedlings enhanced their ability to acquire $\mathrm{N}$ by increasing $\mathrm{N}$ distribution in roots and altering their dry matter partitioning to favor root growth and by optimizing root architecture. In addition, the preferential allocation of the other elements $(\mathrm{K}, \mathrm{Ca}, \mathrm{Mg}$, $\mathrm{Cu}, \mathrm{B}, \mathrm{Mn}$ and $\mathrm{Zn}$ in $\mathrm{N}$ deficiency roots (Figures S5 and S6) might contribute to higher ratio of root DW/shoot DW (Figure 1).

\subsection{Possible Causes for N-Deficiency-Induced Decrease in $A_{\mathrm{CO} 2}$ in Leaves}

Regressive analysis showed that leaf $\mathrm{A}_{\mathrm{CO} 2}$ (PNUE) was positively (negatively) related to leaf $\mathrm{N}$ concentration, but negatively (positively) related to leaf $\mathrm{P} / \mathrm{N}, \mathrm{K} / \mathrm{N}, \mathrm{Ca} / \mathrm{N}, \mathrm{Mg} / \mathrm{N}$, $\mathrm{S} / \mathrm{N}, \mathrm{Fe} / \mathrm{N}, \mathrm{B} / \mathrm{N}$ or $\mathrm{Cu}$ (Figure 10), implying that the imbalance of leaf nutrients might intensify $\mathrm{N}$-deficiency-induced decrease in $\mathrm{A}_{\mathrm{CO} 2}$. The higher $\mathrm{C}_{\mathrm{i}}$ and $\mathrm{C}_{\mathrm{i}} / \mathrm{C}_{\mathrm{a}}$ in $\mathrm{N}$-deficient leaves (Figure 6) and negative relationships between $A_{C O}$ and $C_{i}$ as well as $A_{C O}$ and $\mathrm{C}_{\mathrm{i}} / \mathrm{C}_{\mathrm{a}}$ (Figure 10) indicated that $\mathrm{N}$-deficiency-induced decrease in $\mathrm{A}_{\mathrm{CO} 2}$ was mainly caused by non-stomatal factors, as obtained in 'Cleopatra mandarin' (Citrus reticulata L.) [10], apple [12], grape [78], rice [47] and soybean [79]. However, Zhao et al. [15] suggested 
that $\mathrm{N}$-deficiency-induced decrease in sorghum leaf $\mathrm{A}_{\mathrm{CO} 2}$ was firstly caused by stomatal closure, because both $\mathrm{C}_{\mathrm{i}}$ and $\mathrm{g}_{\mathrm{s}}$ decreased with the decrease in $\mathrm{A}_{\mathrm{CO} 2}$.

Both Chl and Car, the important photosynthetic pigments, were lowered in $\mathrm{N}$ deficiency Citrus leaves (Figure 7). Chl is a key component of photosynthesis, responsible for the absorption, transportation and transformation of light energy. Many studies have shown that leaf $\mathrm{A}_{\mathrm{CO} 2}$ decrease with the decrease in Chl level $[9,14,22]$. Apart from general non-photochemical quenching (NPQ), Car can effectively quench the excited triplet state of $\mathrm{Chl}$ and ${ }^{1} \mathrm{O}_{2}$ and protect thylakoid membranes, PSI and PSII from reactive oxygen species (ROS) damage $[79,80]$. We found that leaf $\mathrm{A}_{\mathrm{CO} 2}$ significantly decreased with the decrease in Chl, Chl $a, \mathrm{Chl} b$ or Car level (Figure 10), that under $\mathrm{N}$ deficiency stress, the decrease in $\mathrm{Chl}$ in C. sinensis leaves was greater than that of $\mathrm{A}_{\mathrm{CO} 2}$, while the decrease in Chl and $\mathrm{A}_{\mathrm{CO} 2}$ in C. grandis leaves was not significantly different, and that Car declined less in C. grandis leaves relative to $\mathrm{A}_{\mathrm{CO} 2}$ in response to $\mathrm{N}$ deficiency, while the decrease in Car and $\mathrm{A}_{\mathrm{CO} 2}$ in C. sinensis leaves did not significantly differ (Figures 6 and 7). N-deficiency-induced decrease in photosynthetic pigments might play a role in $\mathrm{A}_{\mathrm{CO} 2}$ decline, at least in $C$. sinensis leaves. Zhao et al. [15] observed increased $\mathrm{A}_{\mathrm{CO} 2} / \mathrm{Chl}$ ratio in $\mathrm{N}$-limited sorghum leaves, concluding that the higher $\mathrm{A}_{\mathrm{CO} 2} / \mathrm{Chl}$ ratio might partially alleviate negative effects of $\mathrm{N}$ deficiency on $\mathrm{A}_{\mathrm{CO} 2}$. N-deficiency-induced an increase in $\mathrm{A}_{\mathrm{CO} 2} / \mathrm{Chl}$ ratio has been obtained in maize [81]. The ratio of $\mathrm{Chl} a / b$ was significantly lowered in $\mathrm{N}$ deficiency $C$. grandis leaves due to the more reduction in Chl $a$ relative to $\mathrm{Chl} b$, but not in $\mathrm{N}$ deficiency $C$. sinensis leaves (Figure 7). There were mixed reports on $\mathrm{N}$ deficiency's effects on $\mathrm{Chl} a / b$ ratio; $\mathrm{N}$ deficiency decreased the ratio in apple [12] and Citrus medica L. [22], increased it in 'Cleopatra mandarin' [10] and maize [23,69], but had no influence on it in soybean, Populus and rice [9]. Under $\mathrm{N}$ deficiency, Car decreased less relative to $\mathrm{Chl}$ in leaves, and the ratio of $\mathrm{Car} / \mathrm{Chl}$ increased (Figure 6). Similar results have been obtained on B. pendula and B. pubescens [82], C. medica [22], and sweetpotato [77]. A higher ratio of Car/Chl (Figure 7) might be an adaptation mechanism of photosynthetic function to $\mathrm{N}$ deficiency by protecting thylakoid membranes, PSI and PSII from photo-oxidative damage [78,82].

Nutrient deficiencies, including $\mathrm{N}$ deficiency, can cause photoinhibition of PSII, thereby lowering leaf photosynthetic rate $[14,20,26,29,33,34]$. As expected, photoinhibition of PSII was observed in N-deficient leaves [83], as indicated by lower $\mathrm{F}_{\mathrm{v}} / \mathrm{F}_{\mathrm{m}}$ and $\mathrm{ET}_{\mathrm{o}} / \mathrm{ABS}$, and higher $\mathrm{DI}_{\mathrm{o}} / \mathrm{RC}, \mathrm{DI}_{\mathrm{o}} / \mathrm{CS}_{\mathrm{o}}$ and $\mathrm{DI}_{\mathrm{o}} / \mathrm{ABS}$, as well as markedly altered OJIP transients relative to $20 \mathrm{mM} \mathrm{N}$-treated leaves (Figures 8 and 9). The decline of $F_{v} / F_{m}$ in response to $\mathrm{N}$ deficiency was caused by an increase in $\mathrm{F}_{\mathrm{o}}$, because $\mathrm{F}_{\mathrm{m}}$ increased in $\mathrm{N}$ deficiency $C$. sinensis leaves and did not significantly alter in $\mathrm{N}$ deficiency $C$. grandis leaves relative to $20 \mathrm{mM} \mathrm{N}$-treated leaves. A higher $\mathrm{F}_{\mathrm{O}}$ usually occurs in the damaged antennal complex, which cannot effectively transfer energy to the RC [29]. The increase in $F_{o}$ has been suggested to results from the decoupling of PSII light-harvesting complex (LHCII) from PSII rather than the degradation of LHCII [20].

The decrease in $\mathrm{F}_{\mathrm{v}} / \mathrm{F}_{\mathrm{O}}$ indicated that the thylakoid structure of $\mathrm{N}$-deficient leaves was damaged [84]. N-deficiency-induced damage of chloroplast (thylakoid) ultrastructure has been observed by confocal laser scanning and/or transmission electron microscopy in radish [28] and 'Cleopatra mandarin' [10] leaves. There was report suggesting that the reduction in Citrus leaf $\mathrm{A}_{\mathrm{CO} 2}$ in response to $\mathrm{N}$ deficiency was the direct consequence of the destruction of thylakoid assembly [10]. Regressive analysis showed that $\mathrm{F}_{\mathrm{v}} / \mathrm{F}_{\mathrm{o}}$ was significantly and positively to leaf $\mathrm{A}_{\mathrm{CO} 2}, \mathrm{Chl}, \mathrm{Chl} a, \mathrm{Chl} b$ or Car $(r>0.9251)$ (Figure 10). Lack of $\mathrm{N}$, therefore, damaged the structure of thylakoids, thus lowering leaf photosynthetic pigment levels and $\mathrm{A}_{\mathrm{CO} 2}$.

The positive $\mathrm{O}-\mathrm{K}(\Delta \mathrm{L}-)$ band in $\mathrm{N}$-deficient leaves corresponded to less connected antennae complexes with lower energy transfer and absorption efficiency due to improper membrane organization [29] and more fragile PSII units with less stability [85], as indicated by the increase in leaf heterogeneity (Figure S7). The positive O-J ( $\Delta \mathrm{K}-$ ) band in N-deficient leaves resulted from the inhibition of electron donation from the oxygen-evolving complex $(\mathrm{OEC})$ to $\mathrm{P} 60^{+}$due to the inactivation of OEC [86]. The positive O-K $(\Delta \mathrm{L}-)$ and $\mathrm{O}-\mathrm{J}(\Delta \mathrm{K}-)$ 
bands have been obtained in N-deficient tea [14], maize, tomato [28] and radish [20] and various higher plants submitted to other nutrient deficiencies [26,28-30,33,34].

Imbalance in the energetic connectivity between PSII units led to an increase in the inactivation of RCs, as confirmed by the increase in ABS/RC (Figure 8). The inactivation of RCs might protect $\mathrm{N}$-deficient leaves from photooxidative damage by dissipating excessive absorbed light energy $[28,29]$. This agreed with our findings that $\mathrm{N}$ deficiency had higher Car/Chl ratio (Figure 7) and energy dissipation, as confirmed by increased $\mathrm{DI}_{\mathrm{o}} / \mathrm{RC}$, $\mathrm{DI}_{\mathrm{o}} / \mathrm{CS}_{\mathrm{o}}$ and $\mathrm{DI}_{\mathrm{o}} / \mathrm{ABS}$ (Figure 9 ).

The positive $\Delta \mathrm{J}$-band (increased $\mathrm{V}_{\mathrm{J}}$ ), $\Delta \mathrm{I}$-band (increased $\mathrm{V}_{\mathrm{I}}$ ) and negative I-P band (decreased maximum amplitude of IP phase) indicated that $\mathrm{N}$ deficiency had more reductive PSII acceptor side, but more oxidative PSI acceptor side. In other word, PSII acceptor side was more sensitive site to N deficiency than PSII donor side; and PSI was less impaired by $\mathrm{N}$ deficiency than that of PSII $[26,87]$. This was also supported by our findings that $\mathrm{N}$-deficient leaves had higher $\mathrm{F}_{\mathrm{o}}$ and lower $\mathrm{F}_{\mathrm{v}}$ relative to $20 \mathrm{mM} \mathrm{N}$-treated leaves, which were the characteristic of photoinhibitory damage at PSII acceptor side [88]. Similar results have been reported in N-deficient tea [14] and rapeseed [29]. Unfortunately, IP phase and I-P normalized curves were not investigated in the reports of Kalaji et al. [29] and Lin et al. [14], respectively.

The decreases in $\mathrm{RE}_{\mathrm{o}} / \mathrm{ET}_{\mathrm{o}}, \mathrm{RE}_{\mathrm{o}} / \mathrm{ABS}, \mathrm{RE}_{\mathrm{o}} / \mathrm{TR}_{\mathrm{o}}, \mathrm{RE}_{\mathrm{o}} / \mathrm{RC}, \mathrm{RE}_{\mathrm{o}} / \mathrm{CS}_{\mathrm{o}}$ and $\mathrm{PI}_{\mathrm{abs} \text {, total }}$ indicated that $\mathrm{N}$ deficiency lowered both the efficiency of electron transport to the PSI end electron acceptors and the reduction in PSI end-electron acceptors. This was confirmed by the more oxidize PSI acceptor side, as confirmed by the decrease in maximum amplitude of IP phase (Figure 9). Similar results have been obtained in N-deficient tea [14], radish [28] and rapeseed [29].

Except for $\mathrm{F}_{\mathrm{v}}$ and $\mathrm{F}_{\mathrm{m}}$, each other fluorescence parameter had a significant positive or negative correlation with leaf $\mathrm{N}$ concentration, leaf $\mathrm{P} / \mathrm{N}, \mathrm{K} / \mathrm{N}, \mathrm{Ca} / \mathrm{N}, \mathrm{Mg} / \mathrm{N}, \mathrm{S} / \mathrm{N}$, $\mathrm{Fe} / \mathrm{N}$, or $\mathrm{B} / \mathrm{N}$ ratio, but the relationships between fluorescence parameters and leaf $\mathrm{N}$ were opposite to those between fluorescence parameters and these ratios (Figure 10). Imbalance of leaf nutrients, therefore, intensified N-deficiency-induced impairment of PETC from the donor side of PSII to the reduction in PSI end-electron acceptors (i.e., photon absorption in LHCII, structural damage of thylakoids, electron supply from OEC, stability of PSII units, $\mathrm{Q}_{\mathrm{A}}$ and plastoquinone reduction at PSII acceptor site, and reductions of PSI end-electron acceptors).

Regressive analysis showed that leaf $\mathrm{A}_{\mathrm{CO} 2}$ increased with the increase in $\mathrm{F}_{\mathrm{v}} / \mathrm{F}_{\mathrm{O}}, \mathrm{S}_{\mathrm{m}}$, $\mathrm{F}_{\mathrm{v}} / \mathrm{F}_{\mathrm{m}}, \mathrm{ET}_{\mathrm{o}} / \mathrm{ABS}, \mathrm{RE}_{\mathrm{o}} / \mathrm{ET}_{\mathrm{o}}, \mathrm{RE}_{\mathrm{o}} / \mathrm{ABS}, \mathrm{ET}_{\mathrm{o}} / \mathrm{TR}_{\mathrm{o}}, \mathrm{RE}_{\mathrm{o}} / \mathrm{TR}_{\mathrm{o}}, \mathrm{ET}_{\mathrm{o}} / \mathrm{RC}, \mathrm{RE}_{\mathrm{o}} / \mathrm{RC}, \mathrm{RE}_{\mathrm{o}} / \mathrm{CS}_{\mathrm{o}}$, maximum amplitude of IP phase or $\mathrm{PI}_{\mathrm{abs}, \text { total }}$, but it decreased with the increase in $\mathrm{F}_{\mathrm{O}}$, $\mathrm{M}_{\mathrm{O}}, \mathrm{V}_{\mathrm{J}}, \mathrm{V}_{\mathrm{I}}, \mathrm{TR}_{\mathrm{o}} / \mathrm{RC}, \mathrm{ABS} / \mathrm{RC}, \mathrm{DI}_{\mathrm{o}} / \mathrm{RC}, \mathrm{DI}_{\mathrm{o}} / \mathrm{CS}_{\mathrm{o}}$ or $\mathrm{DI}_{\mathrm{o}} / \mathrm{ABS}$. The exceptions were that leaf $A_{\mathrm{CO} 2}$ was not significantly related to $\mathrm{F}_{\mathrm{v}}$ or $\mathrm{F}_{\mathrm{m}}$ (Figure 10). These results of this study indicated that the impairment of PETC in N-deficient leaves might contribute to the decrease in $\mathrm{A}_{\mathrm{CO} 2}$.

\section{Conclusions}

The results of this study clearly demonstrated that $\mathrm{N}$ deficiency decreased $\mathrm{N}$ uptake and $\mathrm{N}$ concentration in roots, stems and leaves and disturbed nutrient balance and homeostasis in plants, thus reducing plant growth, as well as lowering photosynthetic pigment levels, impairing thylakoid structure and whole PETC in leaves, and thereby decreasing $\mathrm{A}_{\mathrm{CO} 2}$ (Figure 11). The imbalance of nutrients intensified $\mathrm{N}$ deficiency adverse impacts on biomass, photosynthetic pigment biosynthesis, PETC and $\mathrm{A}_{\mathrm{CO} 2}$. Citrus seedlings displayed adaptive responses to $\mathrm{N}$ deficiency, including (a) increasing the distributions of $\mathrm{N}$ and other elements in roots, as well as root DW/shoot DW ratio and root-surface-per-unit volume and (b) enhancing PNUE (Figure 11). The tolerance of $C$. grandis seedlings to $N$ deficiency was slightly higher than that of $C$. sinensis seedlings, which might be related to the higher PNUE of the former. This study provided some novel information on the physiological adaption of Citrus to N-deficiency. 


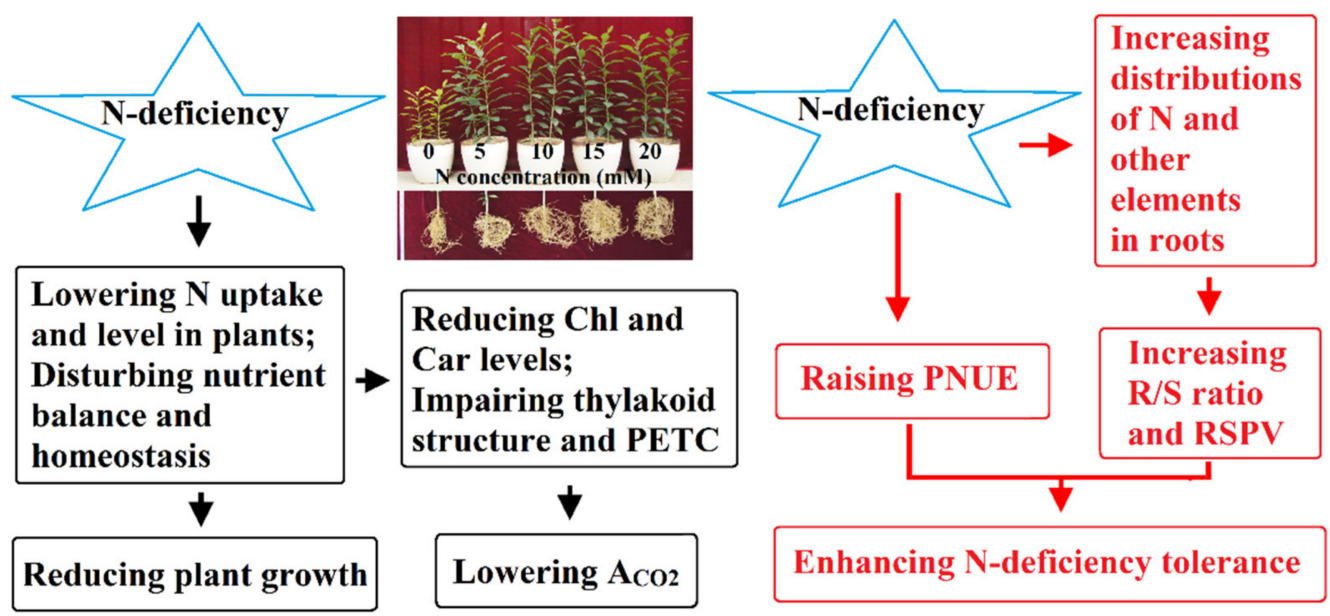

Figure 11. A diagram for the physiological response of $C$. grandis and C. sinensis seedlings to $\mathrm{N}$ deficiency. $\mathrm{A}_{\mathrm{CO} 2}, \mathrm{CO}_{2}$ assimilation; Car, Carotenoids; Chl, chlorophyll; N, nitrogen; PETC, photosynthetic electron transport chain; PNUE, photosynthetic N use efficiency; R/S, root DW/shoot DW; RSPV, root-surface-per-unit volume.

Supplementary Materials: The following are available online at https:/ /www.mdpi.com/article/10 .3390 /agronomy11091859/s1, Figure S1: Effects of nitrogen (N) supply on growth of Citrus sinensis $(\mathrm{A}, \mathrm{B})$ and Citrus grandis $(\mathrm{C}, \mathrm{D})$ seedlings, Figure S2: Effects of $\mathrm{N}$ supply on mean $( \pm \mathrm{SE}, n=4)$ ratios of $\mathrm{P}, \mathrm{K}, \mathrm{Ca}, \mathrm{Mg}$ or $\mathrm{S}$ concentration to $\mathrm{N}$ concentration in leaves (A-E), stems (F-J) and roots (K-O) of Citrus grandis and Citrus sinensis seedlings, Figure S3: Effects of $\mathrm{N}$ supply on mean $( \pm \mathrm{SE}, n=4)$ ratios of $\mathrm{Fe}, \mathrm{Mn}, \mathrm{B}, \mathrm{Zn}$ or $\mathrm{Cu}$ concentration to $\mathrm{N}$ concentration in leaves (A-E), stems (F-J) and roots (K-O) of Citrus grandis and Citrus sinensis seedlings, Figure S4: Matrices of Pearson correlation coefficients (PCCs) for the mean whole plant DW $(n=12)$, element uptake per plant (plant total element content) and the ratio of element uptake per plant to $\mathrm{N}$ uptake per plant $(n=4)$ in $C$. grandis and $C$. sinensis seedlings, Figure S5: Effects of N supply on mean $( \pm \mathrm{SE}, n=4) \mathrm{N}, \mathrm{P}, \mathrm{K}, \mathrm{Ca}, \mathrm{Mg}$ and S distribution in roots $(\mathrm{A}-\mathrm{F})$, stems $(\mathrm{G}-\mathrm{L})$ and leaves $(\mathrm{M}-\mathrm{R})$ of Citrus grandis and Citrus sinensis seedlings, Figure $\mathrm{S6}$ : Effects of N supply on mean $( \pm \mathrm{SE}, n=4) \mathrm{Cu}, \mathrm{B}, \mathrm{Fe} \mathrm{Mn}$ and $\mathrm{Zn}$ distribution in roots (A-E), stems (F-J) and leaves (K-O) of Citrus grandis and Citrus sinensis seedlings, Figure S7: Effects of N supply on the high-light-induced OJIP transients of dark-adapted C. grandis (A-E) and C. sinensis (F-J) leaves plotted on a logarithmic time scale $(0.01$ to $1000 \mathrm{~ms})$.

Author Contributions: Conceptualization, Y.-Z.X. and L.-S.C.; Data curation, W.-T.H.; Formal analysis, W.-T.H.; Funding acquisition, L.-S.C.; Investigation, W.-T.H., X.-F.C., J.Z., H.-H.C., X.Y., J.G. and L.-T.Y.; Methodology, W.-T.H., X.-F.C., J.Z., H.-H.C. and L.-S.C.; Project administration, L.S.C.; Resources, Y.-Z.X.; Supervision, X.Y., J.G., L.-T.Y. and L.-S.C.; Writing-original draft, W.-T.H.; Writing-review and editing, L.-S.C. All authors have read and agreed to the published version of the manuscript.

Funding: This research was funded by the National Key Research and Development Program of China (2018YFD1000305) and the earmarked fund for China Agriculture Research System (CARS-27).

Data Availability Statement: Data are archived in L.-S. Chen's lab and available upon request.

Conflicts of Interest: The authors declare no conflict of interest.

\section{References}

1. Botelho, R.V.; Müller, M.M. Nutrient redistribution in fruit crops: Physiological implications. In Fruit Crops: Diagnosis and Management of Nutrient Constraints; Srivastava, A.K., Hu, C., Eds.; Elsevier: Amsterdam, The Netherlands, 2020; pp. 33-46.

2. Hawkesford, M.; Horst, W.; Kichey, T.; Lambers, H.; Schjoerring, J.; Møller, I.S.; White, P. Functions of macronutrients. In Marschner's Mineral Nutrition of Higher Plants, 3rd ed.; Marschner, P., Ed.; Academic: Amsterdam, The Netherlands, 2012; pp. 135-189.

3. Chen, G.; Wang, L.; Fabrice, M.R.; Tian, Y.; Qi, K.; Chen, Q.; Cao, P.; Wang, P.; Zhang, S.; Wu, J.; et al. Physiological and nutritional responses of pear seedlings to nitrate concentrations. Front. Plant Sci. 2018, 9, 1679. [CrossRef] [PubMed] 
4. Srivastava, A.K. Nutrient deficiency symptomology in Citrus: An effective diagnostic tool or just an aid for post-mortem analysis. Agric. Adv. 2013, 2, 177-194.

5. Chapman, H.D. The mineral nutrition of Citrus. In The Citrus Industry; Reuther, W., Webber, H.J., Batchelor, L.D., Eds.; Division of Agricultural Sciences, University of California: Berkeley, CA, USA, 1968; Volume 2, pp. 127-189.

6. Gao, K.; Chen, F.; Yuan, L.; Zhang, F.; Mi, G. A comprehensive analysis of root morphological changes and nitrogen allocation in maize in response to low nitrogen stress. Plant Cell Environ. 2015, 38, 740-750. [CrossRef] [PubMed]

7. FAOSTAT. Available online: http://www.fao.org/faostat/zh/\#data/RFN (accessed on 2 September 2021).

8. Qin, L.; Walk, T.C.; Han, P.; Chen, L.; Zhang, S.; Li, Y.; Hu, X.; Xie, L.; Yang, Y.; Liu, J.; et al. Adaption of roots to nitrogen deficiency revealed by 3D quantification and proteomic analysis. Plant Physiol. 2019, 179, 329-347. [CrossRef]

9. $\mathrm{Mu}, \mathrm{X} . ; \mathrm{C}$ en, Y. The physiological response of photosynthesis to nitrogen deficiency. Plant Physiol. Biochem. 2021, 158, 76-82. [CrossRef]

10. Bondada, B.R.; Syvertsen, J.P. Leaf chlorophyll, net gas exchange and chloroplast ultrastructure in Citrus leaves of different nitrogen status. Tree Physiol. 2003, 23, 539-553. [CrossRef]

11. Chen, L.-S.; Cheng, L. Carbon assimilation and carbohydrate metabolism of 'Concord' grape leaves in responses to nitrogen supply. J. Am. Soc. Hortic. Sci. 2003, 128, 754-760. [CrossRef]

12. Chen, L.-S.; Cheng, L. Photosynthetic enzymes and carbohydrate metabolism of apple leaves in response to nitrogen limitation. J. Hortic. Sci. Biotechnol. 2004, 79, 923-930. [CrossRef]

13. Peng, J.; Feng, Y.; Wang, X.; Li, J.; Xu, G.; Phonenasay, S.; Luo, Q.; Han, Z.; Lu, W. Effects of nitrogen application rate on the photosynthetic pigment, leaf fluorescence characteristics, and yield of indica hybrid rice and their interrelations. Sci. Rep. 2021, 11, 7485. [CrossRef]

14. Lin, Z.-H.; Zhong, Q.-S.; Chen, C.-S.; Ruan, Q.-C.; Chen, Z.-H.; You, X.-M. Carbon dioxide assimilation and photosynthetic electron transport of tea leaves under nitrogen deficiency. Bot. Stud. 2016, 57, 37. [CrossRef]

15. Zhao, D.; Reddy, K.R.; Kakani, V.G.; Reddy, V.R. Nitrogen deficiency effects on plant growth, leaf photosynthesis, and hyperspectral reflectance properties of sorghum. Eur. J. Agron. 2005, 22, 391-403. [CrossRef]

16. Huang, Z.-A.; Jiang, D.-A.; Yang, Y.; Sun, J.-W.; Jin, S.-H. Effects of nitrogen deficiency on gas exchange, chlorophyll fluorescence, and antioxidant enzymes in leaves of rice plants. Photosynthetica 2004, 42, 357-364. [CrossRef]

17. Cruz, J.L.; Mosquim, P.R.; Pelacani, C.R.; Araújo, W.L.; DaMatta, F.M. Photosynthesis impairment in cassava leaves in response to nitrogen deficiency. Plant Soil 2003, 257,417-423. [CrossRef]

18. Cechin, I. Photosynthesis and chlorophyll fluorescence in two hybrids of sorghum under different nitrogen and water regimes. Photosynthetica 1998, 35, 233-240. [CrossRef]

19. Heitholt, J.J.; Johnson, R.C.; Ferris, D.M. Stomatal limitation to carbon dioxide assimilation in nitrogen and drought-stressed wheat. Crop Sci. 1991, 31, 135-139. [CrossRef]

20. Cetner, M.D.; Kalaji, H.M.; Goltsev, V.; Aleksandrov, V.; Kowalczyk, K.; Borucki, W.; Jajoo, A. Effects of nitrogen-deficiency on efficiency of light-harvesting apparatus in radish. Plant Physiol. Biochem. 2017, 119, 81-92. [CrossRef]

21. Jin, X.; Yang, G.; Tan, C.; Zhao, C. Effects of nitrogen stress on the photosynthetic $\mathrm{CO}_{2}$ assimilation, chlorophyll fluorescence, and sugar-nitrogen ratio in corn. Sci. Rep. 2015, 5, 9311. [CrossRef]

22. Guo, W.-D.; Sang, D.; Zheng, J.-S.; Lai, H.-B.; Chen, W.-T. Effects of nitrogen deficiency on the gas exchange, chlorophyll fluorescence and chloroplast ultrastructure in fingered citron. J. Zhejiang Univ. Agric. Life Sci. 2009, 35, 307-314.

23. Lu, C.; Zhang, J. Photosynthetic $\mathrm{CO}_{2}$ assimilation, chlorophyll fluorescence and photoinhibition as affected by nitrogen deficiency in maize plants. Plant Sci. 2000, 151, 135-143. [CrossRef]

24. Verhoeven, A.S.; Demmig-Adams, B.; Adams, W.W., III. Enhanced employment of the xanthophyll cycle and thermal energy dissipation in spinach exposed to high light and N stress. Plant Physiol. 1997, 113, 817-824. [CrossRef] [PubMed]

25. Lu, C.; Zhang, J.; Zhang, Q.; Li, L.; Kuang, T. Modification of photosystem II photochemistry in nitrogen deficient maize and wheat plants. J. Plant Physiol. 2001, 158, 1423-1430. [CrossRef]

26. Ye, X.; Chen, X.-F.; Deng, C.-L.; Yang, L.-T.; Lai, N.-W.; Guo, J.-X.; Chen, L.-S. Magnesium-deficiency effects on pigments, photosynthesis and photosynthetic electron transport of leaves, and nutrients of leaf blades and veins in Citrus sinensis seedlings. Plants 2019, 8, 389. [CrossRef]

27. Carstensen, A.; Herdean, A.; Schmidt, S.B.; Sharma, A.; Spetea, C.; Pribil, M.; Husted, S. The mmpacts of phosphorus deficiency on the photosynthetic electron transport chain. Plant Physiol. 2018, 177, 271-284. [CrossRef]

28. Kalaji, H.M.; Oukarroum, A.; Alexandrov, V.; Kouzmanova, M.; Brestic, M.; Zivcak, M.; Samborska, I.A.; Cetner, M.D.; Allakhverdiev, S.I.; Goltsev, V. Identification of nutrient deficiency in maize and tomato plants by in vivo chlorophyll a fluorescence measurements. Plant Physiol. Biochem. 2014, 281, 16-25. [CrossRef] [PubMed]

29. Kalaji, H.M.; Bąba, W.; Gediga, K.; Goltsev, V.; Samborska, I.A.; Cetner, M.D.; Dimitrovam, S.; Piszcz, U.; Bielecki, K.; Karmowska, K.; et al. Chlorophyll fluorescence as a tool for nutrient status identification in rapeseed plants. Photosynth. Res. 2018, 136, 329-343. [CrossRef]

30. Aleksandrov, V.; Krasteva, V.; Paunov, M.; Chepisheva, M.; Kousmanova, M.; Kalaji, H.M.; Goltsev, V. Deficiency of some nutrient elements in bean and maize plants analyzed by luminescent method. Bulg. J. Agric. Sci. 2014, 20, 24-30.

31. Schmidt, S.B.; Pedas, P.; Laursen, K.H.; Schjoerring, J.K.; Husted, S. Latent manganese deficiency in barley can be diagnosed and remediated on the basis of chlorophyll a fluorescence measurements. Plant Soil 2013, 372, 417-429. [CrossRef] 
32. Yang, G.-H.; Yang, L.-T.; Jiang, H.-X.; Wang, P.; Chen, L.-S. Physiological impacts of magnesium-deficiency in Citrus seedlings: Photosynthesis, antioxidant system and carbohydrates. Trees Struct. Funct. 2012, 26, 1237-1250. [CrossRef]

33. Han, S.; Tang, N.; Jiang, H.-X.; Yang, L.-T.; Li, Y.; Chen, L.-S. $\mathrm{CO}_{2}$ assimilation, photosystem II photochemistry, carbohydrate metabolism and antioxidant system of Citrus leaves in response to boron stress. Plant Sci. 2009, 176, 143-153. [CrossRef]

34. Lin, Z.-H.; Chen, L.-S.; Chen, R.-B.; Zhang, F.-Z.; Jiang, H.-X.; Tang, N. CO ${ }_{2}$ assimilation, ribulose-1,5-bisphosphate carboxylase/oxygenase, carbohydrates and photosynthetic electron transport probed by the JIP-test, of tea leaves in response to phosphorus supply. BMC Plant Biol. 2009, 9, 43. [CrossRef]

35. De Souza Osório, C.R.W.; Marques Teixeira, G.C.; Barreto, R.F.; Silva Campos, C.N.; Freitas Leal, A.J.; Teodoro, P.E.; de Mello Prado, R. Macronutrient deficiency in snap bean considering physiological, nutritional, and growth aspects. PLoS ONE 2020, 15, e0234512. [CrossRef] [PubMed]

36. Zhu, Z.; Li, D.; Wang, P.; Li, J.; Lu, X. Transcriptome and ionome analysis of nitrogen, phosphorus and potassium interactions in sorghum seedlings. Theor. Exp. Plant Physiol. 2020, 32, 271-285. [CrossRef]

37. Deng, B.; Li, Y.; Lei, G.; Liu, G. Effects of nitrogen availability on mineral nutrient balance and flavonoid accumulation in Cyclocarya paliurus. Plant Physiol. Biochem. 2019, 135, 111-118. [CrossRef] [PubMed]

38. Shah, J.-M.; Bukhari, S.-A.; Zeng, J.-B.; Quan, X.-Y.; Ali, E.; Muhammad, N.; Zhang, G.P. Nitrogen (N) metabolism related enzyme activities, cell ultrastructure and nutrient contents as affected by $\mathrm{N}$ level and barley genotype. J. Integr. Agric. 2017, 16, 190-198. [CrossRef]

39. Wang, Z.-Q.; Wu, L.-H.; Liu, T.-T.; Chu, Y.-W.; Shao, X.-L. Effect of different nitrogen rates on Parthenocissus tricuspidata Planch seedling growth and nutrient distribution. Acta Ecol. Sin. 2007, 27, 3435-3441.

40. Yeh, D.M.; Lin, L.; Wright, C.J. Effects of mineral nutrient deficiencies on leaf development, visual symptoms and shoot-root ratio of Spathiphyllum. Sci. Hortic. 2000, 86, 223-233. [CrossRef]

41. Lal, K.N.; De, R. Elemental composition of sugar-cane leaf and stem in relation to nitrogen deficiency. Nature 1951, 167, 731-732. [CrossRef]

42. Nasr Esfahani, M.; Inoue, K.; Nguyen, K.H.; Chu, H.D.; Watanabe, Y.; Kanatani, A.; Burritt, D.J.; Mochida, K.; Tran, L.P. Phosphate or nitrate imbalance induces stronger molecular responses than combined nutrient deprivation in roots and leaves of chickpea plants. Plant Cell Environ. 2021, 44, 574-597. [CrossRef]

43. Xin, W.; Zhang, L.; Gao, J.; Zhang, W.; Yi, J.; Zhen, X.; Bi, C.; He, D.; Liu, S.; Zhao, X. Adaptation mechanism of roots to low and high nitrogen revealed by proteomic analysis. Rice 2021, 14, 5. [CrossRef]

44. Sorgonà, A.; Abenavoli, M.R. Nitrogen in Citrus: Signal, nutrient, and use efficiency. In Advances in Citrus Nutrition; Srivastava, A.K., Ed.; Springer: Dordrecht, The Netherlands, 2012; pp. 231-244.

45. Sorgonà, A.; Abenavoli, M.R.; Gringeri, P.G.; Cacco, G. Comparing morphological plasticity of root orders in slow- and fastgrowing Citrus rootstocks supplied with different nitrate levels. Ann. Bot. 2007, 100, 1287-1296. [CrossRef]

46. Hermans, C.; Hammond, J.P.; White, P.J.; Verbruggen, N. How do plants respond to nutrient shortage by biomass allocation? Trends Plant Sci. 2006, 11, 610-617. [CrossRef]

47. Shao, C.-H.; Qiu, C.-F.; Qian, Y.-F.; Liu, G.-R. Nitrate deficiency decreased photosynthesis and oxidation-reduction processes, but increased cellular transport, lignin biosynthesis and flavonoid metabolism revealed by RNA-Seq in Oryza sativa leaves. PLoS ONE 2020, 15, e0235975. [CrossRef]

48. Yang, C.; Yang, Z.; Zhao, L.; Sun, F.; Liu, B. A newly formed hexaploid wheat exhibits immediate higher tolerance to nitrogendeficiency than its parental lines. BMC Plant Biol. 2018, 18, 113. [CrossRef]

49. Quan, X.; Zeng, J.; Han, Z.; Zhang, G. Ionomic and physiological responses to low nitrogen stress in Tibetan wild and cultivated barley. Plant Physiol. Biochem. 2017, 111, 257-265. [CrossRef]

50. Mardanov, A.; Samedovam, A.; Shirvany, T. Root-shoot relationships in plant adaptation to nitrogen deficiency. In Root Demographics and Their Efficiencies in Sustainable Agriculture, Grasslands and Forest Ecosystems; Box, J.E., Jr., Ed.; Kluwer Academic Publishers: Dordrecht, The Netherlands, 1998; pp. 147-154.

51. Ericsson, T. Growth and shoot: Root ratio of seedlings in relation to nutrient availability. Plant Soil 1995, 168-169, 205-214 [CrossRef]

52. Findenegg, G.R. Effect of varied shoot\}root ratio on growth of maize (Zea mays) under nitrogen-limited conditions: Growth experiment and model calculations. In Plant Nutrition-Physiology and Applications; van Beusichem, L., Ed.; Kluwer Academic Publishers: Dordrecht, The Netherlands, 1990; pp. 21-27.

53. Tolley-Henry, L.; Raper, C.D., Jr. Nitrogen and dry-matter partitioning in soybean plants during onset of and recovery from nitrogen stress. Bot. Gaz. 1986, 147, 392-399. [CrossRef] [PubMed]

54. Li, X.; Zeng, R.; Liao, H. Improving crop nutrient efficiency through root architecture modifications. J. Integr. Plant Biol. 2016, 58, 193-202. [CrossRef] [PubMed]

55. Liu, X.-M.; Liu, X.-D.; Liu, W.-D.; Tan, Q.-L.; Hu, X.-X.; Li, J.-X. Nutritional status of different citrus trees and the recommended dosages of N, P and K for Citrus production in China. J. Plant Nutr. Fertil. 2021, 27, 565-574.

56. Chen, H.; Jia, Y.; Xu, H.; Wang, Y.; Zhou, Y.; Huang, Z.; Yang, L.; Li, Y.; Chen, L.-S.; Guo, J. Ammonium nutrition inhibits plant growth and nitrogen uptake in Citrus seedlings. Sci. Hortic. 2020, 272, 109526. [CrossRef]

57. Li, Y.-F.; Zhang, C.-B.; Yi, X.-T.; Ling, L.-L.; Huang, Z.-Y.; Shi, Y.-T.; Hu, T.-H.; Zhang, R.; Li, Y.-Q.; Zi, L.-L.; et al. Characteristics of soil nutrients and frequency distribution of Yuxi Citrus orchards in Yunnan. Soils 2020, 52, 487-493. 
58. Zhu, L.-Q.; Shen, X.-J.; Zhou, S.-L.; Zeng, Y.; Peng, L.-Z.; Fu, X.-Z.; Ling, L.-L.; Chen, C.-P. Effects of nitrogen stresses on the nitrogen metabolism and expression of related genes in Poncirus trifoliata and 'Ziyang Xiangcheng' (Citrus junos) rootstocks. J. Fruit Sci. 2020, 37, 449-458.

59. Yang, J.-B.; Zhang, J.; Li, J.-J.; Zheng, Y.-Q.; Lü, Q.; Xie, R.-J.; Ma, Y.-Y.; Deng, L.; He, S.-L.; Yi, S.-L. Effects of nitrogen application levels on nutrient, yieId and quality of Tarocco blood orange and soil physicochemical properties in the Three Gorges Area of Chongqing. Sci. Agric. Sin. 2019, 52, 893-908.

60. Li, Y.; Han, M.-Q.; Lin, F.; Ten, Y.; Lin, J.; Zhu, D.-H.; Guo, P.; Weng, Y.-B.; Chen, L.-S. Soil chemical properties, 'Guanximiyou' pummelo leaf mineral nutrient status and fruit quality in the southern region of Fujian province, China. J. Soil Sci. Plant Nutr. 2015, 15, 615-628. [CrossRef]

61. Lu, J.-W.; Chen, F.; Wang, Y.-H.; Liu, D.-B.; Wan, Y.-F.; Yu, C.-B. Effect of N, P, K fertilization on young Citrus tree growth, fruit yield and quality in area of red soil. Plant Nutr. Fertil. Sci. 2004, 10, 413-418.

62. Yang, T.-Y.; Cai, L.-Y.; Qi, Y.-P.; Yang, L.-T.; Lai, N.-W.; Chen, L.-S. Increasing nutrient solution pH alleviated aluminum-induced inhibition of growth and impairment of photosynthetic electron transport chain in Citrus sinensis seedlings. BioMed Res. Int. 2019, 2019, 9058715. [CrossRef]

63. Lichtenthaler, H.K. Chlorophylls and carotenoids: Pigments of photosynthetic biomembranes. Methods Enzymol. 1987, 148, 350-382.

64. Cai, L.-Y.; Zhang, J.; Ren, Q.-Q.; Lai, Y.-H.; Peng, M.-Y.; Deng, C.-L.; Ye, X.; Yang, L.-T.; Huang, Z.-R.; Chen, L.-S. Increased $\mathrm{pH}$-mediated alleviation of copper-toxicity and growth response function in Citrus sinensis seedlings. Sci. Hortic. 2021, 288, 110310. [CrossRef]

65. Long, A.; Zhang, J.; Yang, L.-T.; Ye, X.; Lai, N.-W.; Tan, L.-L.; Lin, D.; Chen, L.-S. Effects of low pH on photosynthesis, related physiological parameters and nutrient profile of Citrus. Front. Plant Sci. 2017, 8, 185. [CrossRef] [PubMed]

66. Boussadia, O.; Steppe, K.; Zgallai, H.; Ben El Hadj, S.; Braham, M.; Lemeur, R.; Van Labeke, M.C. Effects of nitrogen deficiency on leaf photosynthesis, carbohydrate status and biomass production in two olive cultivars 'Meski' and 'Koroneiki'. Sci. Hortic. 2010, 123, 336-342. [CrossRef]

67. Jiang, H.-X.; Chen, L.-S.; Zheng, J.-G.; Han, S.; Tang, N.; Smith, B.R. Aluminum-induced effects on photosystem II photochemistry in Citrus leaves assessed by the chlorophyll a fluorescence transient. Tree Physiol. 2008, 28, 1863-1871. [CrossRef] [PubMed]

68. Sang, W.; Huang, Z.-R.; Qi, Y.-P.; Yang, L.-T.; Guo, P.; Chen, L.-S. An investigation of boron-toxicity in leaves of two Citrus species differing in boron-tolerance using comparative proteomics. J. Proteom. 2015, 123, 128-146. [CrossRef] [PubMed]

69. Mu, X.; Chen, Q.; Chen, F.; Yuan, L.; Mi, G. Within-leaf nitrogen allocation in adaptation to low nitrogen supply in maize during grain-filling stage. Front. Plant Sci. 2016, 7, 699. [CrossRef]

70. Chen, Y.; Xiao, C.; Chen, X.; Li, Q.; Zhang, J.; Chen, F.; Yuan, L.; Mi, G. Characterization of the plant traits contributed to high grain yield and high grain nitrogen concentration in maize. Field Crops Res. 2014, 159, 1-9. [CrossRef]

71. Schlüter, U.; Mascher, M.; Colmsee, C.; Scholz, U.; Bräutigam, A.; Fahnenstich, H.; Sonnewald, U. Maize source leaf adaptation to nitrogen deficiency affects not only nitrogen and carbon metabolism but also control of phosphate homeostasis. Plant Physiol. 2012, 60, 1384-1406. [CrossRef]

72. Schreiner, R.P.; Lee, J.; Skinkis, P.A. N, P, and K supply to pinot noir grapevines: Impact on vine nutrient status, growth, physiology, and yield. Am. J. Enol. Vitic. 2013, 64, 26-38. [CrossRef]

73. Broadley, M.R.; Escobar-Gutiérrez, A.J.; Burns, A.; Burns, I.G. What are the effects of nitrogen deficiency on growth components of lettuce? New Phytol. 2000, 147, 519-526. [CrossRef] [PubMed]

74. Liu, X.; Yin, C.; Xiang, L.; Jiang, W.; Xu, S.; Mao, Z. Transcription strategies related to photosynthesis and nitrogen metabolism of wheat in response to nitrogen deficiency. BMC Plant Biol. 2020, 220, 448.

75. Shangguan, Z.P.; Shao, M.A.; Ren, S.J.; Zhang, L.M.; Xue, Q. Effect of nitrogen on root and shoot relations and gas exchange in winter wheat. Bot. Bull. Acad. Sin. 2004, 45, 49-54.

76. Zhu, Y.; Fan, X.; Hou, X.; Wu, J.; Wang, T. Effect of different levels of nitrogen deficiency on switchgrass seedling growth. Crop J. 2014, 2, 223-234. [CrossRef]

77. Wei, M.; Zhang, A.; Li, H.; Tang, Z.; Chen, X. Growth and physiological response to nitrogen deficiency and re-supply in leaf-vegetable sweetpotato (Ipomoea batatas Lam). Hortscience 2015, 50, 754-758. [CrossRef]

78. Chen, L.-S.; Cheng, L. Both xanthophyll cycle-dependent thermal dissipation and the antioxidant system are up-regulated in grape (Vitis labrusca L. cv. Concord) leaves in responses to N limitation. J. Exp. Bot. 2003, 54, 2165-2175. [CrossRef] [PubMed]

79. Li, M.; Xu, J.; Wang, X.; Fu, H.; Zhao, M.; Wang, H.; Shi, L. Photosynthetic characteristics and metabolic analyses of two soybean genotypes revealed adaptive strategies to low-nitrogen stress. J. Plant Physiol. 2018, 229, 132-141. [CrossRef] [PubMed]

80. Anderson, J.M.; Chow, W.S. Structural and functional dynamics of plant photosystem II. Philos. Trans. R. Soc. Lond. B Biol. Sci. 2002, 357, 1421-1430. [CrossRef] [PubMed]

81. Khamis, S.; Lamaze, T.; Lemoine, Y.; Foyer, C. Adaptation of the photosynthetic apparatus in maize leaves as a result of nitrogen limitation: Relationships between electron transport and carbon assimilation. Plant Physiol. 1990, 94, 1436-1443. [CrossRef] [PubMed]

82. Kalashnikova, I.V.; Migalina, S.V.; Ronzhina, D.A.; Ivanov, L.A.; Ivanova, L.A. Functional response of Betula species to edaphic and nutrient stress during restoration of fly ash deposits in the Middle Urals (Russia). Environ. Sci. Pollut. Res. Int. 2021, 28, 12714-12724. [CrossRef] 
83. Force, L.; Critchley, C.; van Rensen, J.J.S. New fluorescence parameters for monitoring photosynthesis in plants. 1. The effect of illumination on the fluorescence parameters of the JIP-test. Photosynth. Res. 2003, 78, 17-33. [CrossRef]

84. Pereira, W.E.; de Siqueira, D.L.; Martínez, C.A.; Puiatti, M. Gas exchange and chlorophyll fluorescence in four Citrus rootstocks under aluminium stress. J. Plant Physiol. 2000, 157, 513-520. [CrossRef]

85. Chen, L.-S.; Cheng, L. The acceptor side of photosystem II is damaged more severely than the donor side of photosystem II in 'Honeycrisp' apple leaves with zonal chlorosis. Acta Physiol. Plant. 2010, 32, 253-261. [CrossRef]

86. Srivastava, A.; Guisse, B.; Greppin, H.; Strasser, R.J. Regulation of antenna structure and electron transport in photosystem II of Pisum sativum under elevated temperature probed by the fast polyphasic chlorophyll a fluorescence transient: OKJIP. Biochim. Biophys. Acta 1997, 1320, 95-106. [CrossRef]

87. Strasser, R.J.; Tsimilli-Michael, M.; Srivastava, A. Analysis of the chlorophyll a fluorescence transient. In Advances in Photosynthesis and Respiration. Chlorophyll a Fluorescence: A Signature of Photosynthesis; Papageorgiou, G., Govindjee, Eds.; Springer: Dordrecht, The Netherlands, 2004; pp. 321-362.

88. Setlik, I.; Allakhverdiev, S.I.; Nedbal, L.; Setlikova, E.; Klimov, V.V. 1Three types of photosystem II photoinactivation. 1. Damaging processes on the acceptor side. Photosynth. Res. 1990, 23, 39-48. [CrossRef] 